\title{
An integrated first principles and experimental investigation of the relationship between structural rigidity and quantum efficiency in phosphors for solid state lighting
}

\author{
Jungmin $\mathrm{Ha}^{\mathrm{a}^{*}}$, Zhenbin Wang ${ }^{\mathrm{b} *}$, Ekaterina Novitskaya ${ }^{\mathrm{c}}$, Gustavo A. Hirata ${ }^{\mathrm{d}}$, Olivia A. \\ Graeve $^{\mathrm{a}, \mathrm{c}}$, Shyue Ping Ong ${ }^{\mathrm{b} \dagger}$, Joanna McKittrick ${ }^{\mathrm{a}, \mathrm{c} \ddagger}$ \\ * These authors contributed equally to this work. \\ ${ }^{a}$ Materials Science and Engineering Program, ${ }^{b}$ Department of Nanoengineering. \\ ${ }^{\mathrm{c}}$ Department of Mechanical and Aerospace Engineering \\ University of California, San Diego, 9500 Gilman Dr., La Jolla, CA 92093, USA \\ ${ }^{\mathrm{d}}$ Center for Nanoscience and Nanotechnology, Ensenada, Mexico \\ ${ }^{\dagger}$ Corresponding author: Tel : 858-534-2668; E-mail : ongsp@eng.ucsd.edu \\ $\$$ Corresponding author: Tel : 858-534-5425, Fax : 858-534-5698; E-mail : \\ jmckittrick@ucsd.edu
}

\begin{abstract}
In this paper, we outline an integrated approach for exploring novel near-UV excited phosphors. To test the hypothesis of whether high host structural rigidity results in phosphors with high quantum efficiency $(\Phi)$, we calculated the Debye temperatures $(\Theta)$ for 27 host materials using density functional theory calculations. We identified $\mathrm{Eu}^{2+}$-activated $\mathrm{Ca}_{7} \mathrm{Mg}\left(\mathrm{SiO}_{4}\right)_{4}$ and $\mathrm{CaMg}\left(\mathrm{SiO}_{3}\right)_{2}$ as having a relatively high $\Theta=601 \mathrm{~K}$ and $665 \mathrm{~K}$, respectively, and predicted excitation energies of $3.18 \mathrm{eV}(337 \mathrm{~nm})$ and $3.29 \mathrm{eV}(377 \mathrm{~nm})$, respectively, both of which are in good agreement with the results of photoluminescence spectroscopy. However, the measured $\Phi$ for these two phosphors was $<30 \%$, which indicates that $\Theta$ alone is not a sufficient condition for a high $\Phi$. This work demonstrates the potential of combined first-principles calculations and experiments in the discovery and design of novel near-UV excited phosphors.
\end{abstract}

Keywords: First-principles calculation, density functional theory, near-UV phosphors, $\mathrm{Eu}^{2+}$ activation, Debye temperature, quantum efficiency 


\section{INTRODUCTION}

White-light sources based on light-emitting diodes (w-LEDs) have attracted intense interest for next generation solid-state lighting technologies due to their longer lifetime, superior efficiency, and low operating temperatures compared with traditional incandescent bulb and fluorescent lamp technologies [1-3]. The common approach to create white-emitting LEDs is to combine a blue-emitting $(450 \mathrm{~nm})$ InGaN LED with a yellow-emitting phosphor $[4,5]$. The drawbacks of this method are a non-uniform light output and a low color rendering index (CRI) value. An alternative, more attractive approach is to combine a near UV-LED (nUV-LED, 370-410 nm) with blue, green, and red phosphors to produce highefficiency w-LEDs. A high CRI value can be achieved by optimization of phosphor blends and, ultimately, a higher extraction efficiency can be obtained due to a smaller current drop at high driving currents, compared to the blue-emitting LEDs [6-8].

Traditional trial-and-error approaches in the discovery of new blue-, green- and redemitting phosphors for nUV-LED phosphors are time consuming and costly. Recently, new methodologies, such as mineral-inspired prototype evolution $[9,10]$ and single-particlediagnosis [11] have been proposed for the discovery of new phosphors. Although these methods have achieved significant progress for developing new phosphors, in essence, they still focus on the exploration case-by-case.

An alternative approach is to use easily computable or measurable descriptors as a means to screen for various desired properties for phosphors, such as an appropriate excitation wavelength (370-410 nm), a high quantum efficiency (> 80\%), good thermal quenching behavior $\left(<20 \%\right.$ decrease in emission intensity from room temperature to $\left.150^{\circ} \mathrm{C}\right)$, and chemical stability (e.g. moisture stability). For example, the narrow-band descriptor combined with band gap and phase stability was recently proposed to discover promising narrow-band red-emitting phosphors for high-power LEDs in a high throughput approach 
[12]. Based on the analysis of over 1000 rare-earth activated compositions, Dorenbos [13, 14] proposed that the excitation energy, $E_{a}(\mathrm{Re}, \mathrm{A})$ can be predicted from the following empirical relationship:

$$
E_{a}(\mathrm{Re}, \mathrm{A})=E_{F}(\mathrm{Re})-D(\mathrm{~A})
$$

where $E_{F}(\mathrm{Re})$ and $D(\mathrm{~A})$ are the rare earth $(\mathrm{Re})$ free ion energy and crystal field depression in host $\mathrm{A}$, respectively. However, $D(\mathrm{~A})$ is difficult to calculate. It is usually tabulated and strongly related to the crystal structure of the host, therefore it is not easy to use Eqn. (1) for new host materials without knowledge of $D(\mathrm{~A})$.

More recently, the $a b$ initio calculated Debye temperature $(\Theta)$ of host materials was proposed to have a positive relationship with the experimental photoluminescence (PL) quantum efficiency $(\Phi)$. For $\mathrm{Ce}^{3+}$-activated phosphors, a $\Theta \geq 500 \mathrm{~K}$ was suggested for $\Phi \geq$

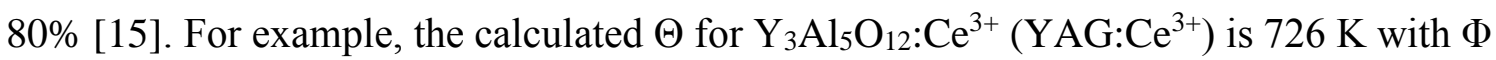
measured to be $90 \%$ [15]. These preliminary results suggest that host materials with a high $\Theta$ may yield high $\Phi$ with an appropriate host band gap. However, there have been relatively few efforts utilizing a combined first-principles and experimental approach for the discovery of new phosphors.

In this work, 27 host materials were selected based on the criterion that $\mathrm{Ce}^{3+}$ - or $\mathrm{Eu}^{2+}$ doping results in an absorption wavelength in the near-UV light range $(370-410 \mathrm{~nm})$. These host materials were found from potential phosphor compositions in the literature $[13,14,16-$ 18]. The $\Theta$ of these 27 hosts were calculated using density functional theory (DFT) calculations. Two potential candidates, $\mathrm{Ca} 7 \mathrm{Mg}\left(\mathrm{SiO}_{4}\right)_{4}: \mathrm{Eu}^{2+}$ and $\mathrm{CaMg}\left(\mathrm{SiO}_{3}\right)^{2}: \mathrm{Eu}^{2+}$ having higher $\Theta$ were identified, and their excitation energies were calculated. Then, powders were synthesized. The $\left(\mathrm{Ca}_{0.96} \mathrm{Eu}_{0.04}\right)_{7} \mathrm{Mg}\left(\mathrm{SiO}_{4}\right)_{4}$ phosphor was prepared by the sol-gel/Pechini method and the $\mathrm{Ca}_{0.94} \mathrm{Eu}_{0.06} \mathrm{Mg}\left(\mathrm{SiO}_{3}\right)_{2}$ phosphor was prepared by the co-precipitation method. Subsequently, the PL properties were analyzed to compare to the first-principles predictions. 


\section{METHODS}

\section{Computational methods}

All first-principles calculations were performed using the projector augmented wave (PAW) method as implemented in the Vienna ab initio simulation package (VASP) $[19,20]$. The Perdew-Berke-Ernzerhoff (PBE) [21] exchange-correlation functional was used. More specific calculation parameters can be found in references [22, 23].

The Debye temperature, $\Theta$, was calculated using the quasi-harmonic model given by [15]

$$
\Theta=\frac{\hbar}{k_{B}}\left(6 \pi^{2} V^{\frac{1}{2}} n\right) f(v) \sqrt{\frac{B}{M}}
$$

where $V, n, f(v), B$ and $M$ are the unit cell volume, the number of atoms in the unit cell, a scaling function in terms of Poisson's ratio $v$, the bulk modulus and the molar mass, respectively; $\hbar$ and $k_{B}$ refer to the Plank constant and the Boltzmann constant, respectively. The elastic moduli were calculated by employing the Voigt-Reuss-Hill (VRH) approximation based on the computed elastic tensor [24]. Previous research indicated that an effective Hubbard $U$ of $2.5 \mathrm{eV}$ can reproduce the experimental $E(\mathrm{VBM}-4 \mathrm{f})$ for $\mathrm{Eu}^{2+}$-activated oxides, [25] and the band width of the $\mathrm{Eu}^{2+} 4 f$ bands are not very sensitive to the $U$ value used [12]. We here adopted $U=2.5 \mathrm{eV}$ for the evaluation of orbital-projected density of states (DOS) with the PBE functional. The band structures of hosts were calculated using the modified Becke-Johnson localized-density functional (MBJLDA), which has been shown to yield more accurate band gap values for insulators compared to the standard generalized gradient approximation (GGA), but at a much lower computational cost compared to hybrid density functionals [26]. 
According to experimental findings on the absolute location of lanthanide $\left(\mathrm{Ce}^{3+}\right.$ and $\mathrm{Eu}^{2+}$ ) energy levels, the $4 f$ and $5 d$ energy levels generally lie in the band gap, with the $5 d$ level closer to the conduction band minimum $[27,28]$. This PL mechanism $\left(4 f^{n-1} 5 d^{1} \rightarrow 4 f^{n}\right.$ transition) for $\mathrm{Ce}^{3+}$ and $\mathrm{Eu}^{2+}$ activated phosphors is described in Figure 1 [27, 28]. The excitation energy $\left(E_{e x}\right)$ is proposed from the following equation:

$$
E_{e x} \approx E_{g}(\text { host, band gap })-E(\mathrm{VBM}-4 f) \text {. }
$$

where $E_{g}$ (host, band gap) is the band gap of the host material and $E(\mathrm{VBM}-4 f)$ is the energy gap between the valence band maximum (VBM) and $4 f$ level. It is noted that there are some errors in the estimate of the excitation energy on the order of $\sim 1 \mathrm{eV}$ due to the neglect of the gap between the ground state Eu5d level and the CBM. Dorenbos [29] found that the excited $\mathrm{Eu} 5 \mathrm{~d}$ level is generally located within about $1.0 \mathrm{eV}$ below the conduction band minimum $(\mathrm{CBM})$. Also, the Stokes shift usually lies in the range of $0.64 \mathrm{eV} \sim 1.22 \mathrm{eV}$. Nevertheless, the relative trend is reasonable. The Fermi energy in $\mathrm{Eu}^{2+}$-activated systems refers to the highest occupied $4 \mathrm{f}$ orbital and is set to zero in the DOS plot.

\section{Synthesis of phosphors}

Reagents

All chemicals were used without further purification and included tetraethyl orthosilicate (TEOS, 99.9\%, Sigma Aldrich), nitric acid (69.3\%, Fisher Scientific), $\mathrm{Eu}_{2} \mathrm{O}_{3}$ (99.99\%, Alfa Aesar), $\mathrm{Mg}\left(\mathrm{NO}_{3}\right)_{2} \bullet 6 \mathrm{H}_{2} \mathrm{O}\left(98.3 \%\right.$, Fisher Scientific), $\mathrm{Ca}\left(\mathrm{NO}_{3}\right)_{2} \bullet 4 \mathrm{H}_{2} \mathrm{O}(99.0 \%$, Macron Fine Chemicals), citric acid $\left(\mathrm{C}_{6} \mathrm{H}_{8} \mathrm{O}_{7} \bullet \mathrm{H}_{2} \mathrm{O}\right.$, Macron Fine Chemicals), ethylene glycol $\left(\mathrm{C}_{2} \mathrm{H}_{6} \mathrm{OH}\right.$, Fisher Scientific), polyethylene glycol $\left(\mathrm{PEG}, \mathrm{C}_{2} \mathrm{H}_{4} \mathrm{O} \cdot \mathrm{nH}_{2} \mathrm{O}\right.$, molecular weight $=$ 20,000 g/mole, Sigma Aldrich), and ammonium hydroxide (28 30\%, BDH Aristar Plus).

Preparation of $\left(\mathrm{Ca}_{0.96} \mathrm{Eu}_{0.04}\right)_{7} \mathrm{Mg}\left(\mathrm{SiO}_{4}\right)_{4}$ 
The sol-gel/Pechini process was used to synthesize $\left(\mathrm{Ca}_{0.96} \mathrm{Eu}_{0.04}\right)_{7} \mathrm{Mg}\left(\mathrm{SiO}_{4}\right)_{4}$ powders. The 4 at. $\% \mathrm{Eu}^{2+}$ concentration was chosen because it has been reported to have the highest PL emission intensity [16]. First, tetraethyl orthosilicate $(2.23 \mathrm{~mL})$ was added to ethanol (20 $\mathrm{mL}$ ) with several drops of nitric acid and stirred for $30 \mathrm{~min}$. Next, $\mathrm{Eu}_{2} \mathrm{O}_{3}$ was added in a dilute nitric acid solution to form a solution of aqueous $\mathrm{Eu}\left(\mathrm{NO}_{3}\right)_{3} \cdot \mathrm{Mg}\left(\mathrm{NO}_{3}\right)_{2} \cdot 6 \mathrm{H}_{2} \mathrm{O}$, and $\mathrm{Ca}\left(\mathrm{NO}_{3}\right)_{2} \bullet 4 \mathrm{H}_{2} \mathrm{O}$ were dissolved in deionized water. After these solutions became transparent, silica sol and the $\mathrm{Eu}\left(\mathrm{NO}_{3}\right)_{3}$ solution were poured to the $\mathrm{Mg}\left(\mathrm{NO}_{3}\right)_{2}$ and $\mathrm{Ca}\left(\mathrm{NO}_{3}\right)_{2}$ solution with stirring. Next, citric acid $(4.2 \mathrm{~g})$ and ethylene glycol $(2.23 \mathrm{~mL})$ were added to the mixed solution (metal:citric acid:ethylene glycol =1:1:2), which acts as a chelating agent for the metal ions. Polyethylene glycol (2.5 g) was introduced in the mixture, which was used as a crosslinking agent. After stirring the solution for 30 minutes to ensure uniformity, precipitation occurred by adding drops of ammonium hydroxide until the $\mathrm{pH}$ reached 4 . After completing the preparation, the mixture was continuously stirred at $80^{\circ} \mathrm{C}$ overnight to form a gel. The white colored product was preheated to remove organic materials at $350^{\circ} \mathrm{C}$ for 1 hour, and then annealed at $1100^{\circ} \mathrm{C}$ or $1350^{\circ} \mathrm{C}$ for $3 \mathrm{~h}$, or $1400^{\circ} \mathrm{C}$ for $10 \mathrm{~h}$ in air. All samples were finally calcined at $1100^{\circ} \mathrm{C}$ for $4 \mathrm{~h}$ under a slight reducing condition (mixture of $5 \% \mathrm{H}_{2}$ and $95 \% \mathrm{~N}_{2}$ ).

Preparation of $\mathrm{Ca}_{0.94} \mathrm{Eu}_{0.06} \mathrm{Mg}\left(\mathrm{SiO}_{3}\right)_{2}$

$\mathrm{Ca}_{1-\mathrm{x}} \mathrm{Eu}_{\mathrm{x}} \mathrm{MgSi}_{2} \mathrm{O}_{6}$ powders were synthesized by a co-precipitation technique that was modified from a previous reported method [30]. TEOS $(2.23 \mathrm{~mL})$ was added into ethanol (20 $\mathrm{mL})$ with $\mathrm{HNO}_{3}(5 \mathrm{~mL})$ and stirred for 30 minutes to hydrolyze TEOS. The desired amount of $\mathrm{Eu}_{2} \mathrm{O}_{3}(x=0.02,0.06,0.1$, and 0.2$)$ was introduced in a dilute nitric acid solution to form a solution of aqueous $\mathrm{Eu}\left(\mathrm{NO}_{3}\right)_{3} \cdot \mathrm{Mg}\left(\mathrm{NO}_{3}\right)_{2} \bullet 6 \mathrm{H}_{2} \mathrm{O}$ and $\mathrm{Ca}\left(\mathrm{NO}_{3}\right)_{2} \bullet 4 \mathrm{H}_{2} \mathrm{O}$ were dissolved in 30 $\mathrm{mL}$ of deionized water. After the europium solution and the magnesium and calcium solution became transparent, the silica sol and europium solution were poured into the magnesium and 
calcium solution and the mixture was stirred for 1 hour. Ammonium hydroxide was added dropwise into the solution until the $\mathrm{pH}$ was 10 to create a white precipitate. The precipitate solution was stirred for $8 \mathrm{~h}$ at room temperature. Next, the precipitate was centrifuged and washed with deionized water three times. The products obtained by centrifugation were dried at $100^{\circ} \mathrm{C}$ for 12 hours. Then a post-annealing step was performed at $1100^{\circ} \mathrm{C}$ for $2 \mathrm{~h}$ under air and then at $1100^{\circ} \mathrm{C}$ for $4 \mathrm{~h}$ under $5 \% \mathrm{H}_{2} / 95 \% \mathrm{~N}_{2}$ to change $\mathrm{Eu}^{3+}$ to $\mathrm{Eu}^{2+}$.

\section{Characterization}

The crystallite phases and crystallite sizes of the annealed powders were determined by X-ray diffraction (XRD, Bruker D2 Phaser) using $\mathrm{CuK} \alpha$ radiation and a step size of $0.014^{\circ}$ over the $2 \theta$ range of 20 to 80 degrees. The analysis was performed using the Diffrac.Eva plus program. Lattice parameters and crystallite sizes were calculated using the approach of Rietveld refinement by the TOPAS 4.2 software (Bruker), which averages the lattice constants associated with each XRD peak across the entire spectrum. The size and morphology of the particles were analyzed by a field emission scanning electron microscope (FESEM, XL30, Philips) at $10 \mathrm{keV}$. Samples were coated with iridium at $85 \mu \mathrm{A}$ for $10 \mathrm{~s}$ before FESEM imaging. Absolute quantum efficiency $(\Phi)$ measurements were performed using an integrating sphere system, with sodium salicylate $(\Phi=44 \%)$ as a reference standard. Photoluminescence emission and excitation spectra were acquired with a fluorescence spectrophotometer (Hitachi F-7000) using $\lambda=350 \mathrm{~nm}$ excitation wavelength (pulse $=0.025$ sec). This excitation wavelength was chosen as it produced the highest PL emission intensity. The thermal quenching analysis $\left(25^{\circ} \mathrm{C} \sim 150{ }^{\circ} \mathrm{C}\right)$ was performed using a custom designed device that consist of a heater, thermocouple, and the spectrophotometer.

\section{RESULTS AND DISCUSSION}


High structural rigidity confines accessible phonon modes that result in non-radiative recombination. As mentioned previously, $\Theta$ was recently proposed as a descriptor of structural rigidity [15]. The higher $\Theta$, the fewer lattice vibration modes can be accessed and thus the more rigid is a crystal structure. The calculated $\Theta$ of the 27 host candidates are summarized in Table 1. Six host candidates (in bold) have $\Theta>500 \mathrm{~K}$, implying a strong rigidity of the crystal structure and correspondingly, a possible high $\Phi$.

Among these six candidates, only the three silicate host materials $\mathrm{Mg}_{2} \mathrm{SiO}_{4}$, $\mathrm{Ca}_{7} \mathrm{Mg}\left(\mathrm{SiO}_{4}\right)_{4}$, and $\mathrm{CaMg}\left(\mathrm{SiO}_{3}\right)_{2}$, were considered further because of their high chemical stability, good thermal quenching properties [31], and facile synthesis methodologies. Since, in $\mathrm{Mg}_{2} \mathrm{SiO}_{4}$ the radius of $\mathrm{Mg}^{2+}(<0.07 \mathrm{~nm})$ is too small to be replaced by $\mathrm{Eu}^{2+}(\sim 0.130 \mathrm{~nm})$, $\mathrm{Ca} 7 \mathrm{Mg}\left(\mathrm{SiO}_{4}\right)_{4}: \mathrm{Eu}^{2+}$ and $\mathrm{CaMg}\left(\mathrm{SiO}_{3}\right)_{2}: \mathrm{Eu}^{2+}$ were selected further. In this case, $\mathrm{Eu}^{2+}$ can replace $\mathrm{Ca}^{2+}$ in the crystal structure due to similar ionic radii $(0.118 \mathrm{~nm}$ and $0.123 \mathrm{~nm}$ for 9coordinated and 10-coordinatd $\mathrm{Ca}^{2+}$, respectively; $0.130 \mathrm{~nm}$ and $0.135 \mathrm{~nm}$ for 9-coordinated and 10-coordinated $\mathrm{Eu}^{2+}$, respectively) [32].

Figures $2 \mathrm{a}$ and $2 \mathrm{~b}$ show the calculated band structures of $\mathrm{Ca}_{7} \mathrm{Mg}\left(\mathrm{SiO}_{4}\right)_{4}$ and $\mathrm{CaMg}\left(\mathrm{SiO}_{3}\right)_{2}$. Both hosts have direct $(\Gamma \rightarrow \Gamma$ transition $)$ band gaps $\left(E_{g}=6.86 \mathrm{eV}\right.$ for $\mathrm{Ca}_{7} \mathrm{Mg}\left(\mathrm{SiO}_{4}\right)_{4}$ and $E_{g}=7.08 \mathrm{eV}$ for $\left.\mathrm{CaMg}\left(\mathrm{SiO}_{3}\right)_{2}\right)$. Figures $3 \mathrm{a}$ and $3 \mathrm{~b}$ show the calculated orbital projected DOS. The energies between $4 f$ (located at Fermi energy level of 0 ) and VBM for $\mathrm{Ca}_{7} \mathrm{Mg}\left(\mathrm{SiO}_{4}\right)_{4}: \mathrm{Eu}^{2+}$ and $\mathrm{CaMg}\left(\mathrm{SiO}_{3}\right)_{2}: \mathrm{Eu}^{2+}$ are $3.18 \mathrm{eV}$ and $3.79 \mathrm{eV}$, respectively. The excitation energies can be estimated from Eqn. (3) by subtracting the calculated $4 f$-VBM gap (3.18 eV for $\mathrm{Ca}_{7} \mathrm{Mg}\left(\mathrm{SiO}_{4}\right)_{4}: \mathrm{Eu}^{2+}$ and $2.79 \mathrm{eV}$ for $\left.\mathrm{CaMg}\left(\mathrm{SiO}_{3}\right)_{2}: \mathrm{Eu}^{2+}\right)$ from $E_{g}$, which gives $E_{e x}=3.68 \mathrm{eV}(337 \mathrm{~nm})$ for $\mathrm{Ca}_{7} \mathrm{Mg}\left(\mathrm{SiO}_{4}\right)_{4}: \mathrm{Eu}^{2+}$ and $3.29 \mathrm{eV}(377 \mathrm{~nm})$ for $\mathrm{CaMg}\left(\mathrm{SiO}_{3}\right)_{2}: \mathrm{Eu}^{2+}$.

Crystal structure, X-ray diffraction, and scanning electron microscopy of the synthesized phosphors 
Figures $4 \mathrm{a}$ and $4 \mathrm{~b}$ show the structures of $\mathrm{Ca} 7 \mathrm{Mg}\left(\mathrm{SiO}_{4}\right)_{4}: \mathrm{Eu}^{2+}$ and $\mathrm{CaMg}\left(\mathrm{SiO}_{3}\right)_{2}: \mathrm{Eu}^{2+}$ drawn by VESTA (Visualization for Electronic and STructural Analysis) [33]. In Figure 4a, $\mathrm{Ca}_{7} \mathrm{Mg}\left(\mathrm{SiO}_{4}\right)_{4}$ (mineral bredigite) has an orthorhombic structure with a space group Pnn2 where $\mathrm{Ca}^{2+}$ has three different crystallographic sites with coordination numbers 12,10 , and 9 [34]. As illustrated in Figure $4 \mathrm{~b}, \mathrm{CaMg}\left(\mathrm{SiO}_{3}\right)_{2}$ (mineral diopside) has a monoclinic structure with space group $C 2 / c$. The lattice parameters of $\left(\mathrm{Ca}_{0.96} \mathrm{Eu}_{0.04}\right)_{7} \mathrm{Mg}\left(\mathrm{SiO}_{4}\right)_{4}$ and $\mathrm{Ca}_{0.94} \mathrm{Eu}_{0.06} \mathrm{Mg}\left(\mathrm{SiO}_{3}\right)_{2}$ were calculated using TOPAS and the computed lattice constants are $a$ $=0.6742 \mathrm{~nm}, b=1.0887 \mathrm{~nm}, c=1.8339 \mathrm{~nm}$ for $\left(\mathrm{Ca}_{0.96} \mathrm{Eu}_{0.04}\right)_{7} \mathrm{Mg}\left(\mathrm{SiO}_{4}\right)_{4}$ and $a=0.9743 \mathrm{~nm}$, $b=0.8879 \mathrm{~nm}, c=0.5230 \mathrm{~nm}$ for $\mathrm{Ca}_{0.94} \mathrm{Eu}_{0.06} \mathrm{Mg}\left(\mathrm{SiO}_{3}\right)_{2}$, which are consistent with previous reports for $\mathrm{Ca}_{7} \mathrm{Mg}\left(\mathrm{SiO}_{4}\right)_{4}[34]$ and $\mathrm{CaMg}\left(\mathrm{SiO}_{3}\right)_{2}$ [35].

XRD patterns of the $\left(\mathrm{Ca}_{0.96} \mathrm{Eu}_{0.04}\right)_{7} \mathrm{Mg}\left(\mathrm{SiO}_{4}\right)_{4}$ powders for different calcination times and temperatures are shown in Figure 5a. The diffraction peaks were indexed by the standard data from PDF card 00-036-0399 $\left.\left(\mathrm{Ca}_{7} \mathrm{MgSi}_{4} \mathrm{O}_{4}\right)_{4}\right)$. A pattern for post-synthesis annealing at $1100^{\circ} \mathrm{C}$, shows impurity peaks around $2 \theta=27,29$ and $30^{\circ}$, which correspond to $\mathrm{CaSiO}_{5}$. However, these peaks disappear after annealing over $1350^{\circ} \mathrm{C}$. No other diffraction peaks, other than those corresponding to $\left(\mathrm{Ca}_{0.96} \mathrm{Eu}_{0.04}\right)_{7} \mathrm{Mg}\left(\mathrm{SiO}_{4}\right)_{4}$, are observed at both $1350^{\circ} \mathrm{C}$ and $1400^{\circ} \mathrm{C}$. The crystallite sizes were determined by the TOPAS program and were $\sim 54 \mathrm{~nm}, \sim 67$ $\mathrm{nm}$, and $\sim 70 \mathrm{~nm}$, for post-synthesis annealing at $1100^{\circ} \mathrm{C}$ for $3 \mathrm{~h}, 1350^{\circ} \mathrm{C}$ for $3 \mathrm{~h}$, and $1400^{\circ} \mathrm{C}$ for $10 \mathrm{~h}$, respectively. These results are in a good agreement with previous studies demonstrating that crystallites grow with an increase of the post-synthesis annealing temperature and time [36, 37].

Figure $5 \mathrm{~b}$ shows $\mathrm{XRD}$ patterns of the $\mathrm{Ca}_{1-\mathrm{x}} \mathrm{Eu}_{\mathrm{x}} \mathrm{MgSi}_{2} \mathrm{O}_{6}(x=0.02,0.06,0.1$, and 0.2$)$ powders. It is observed that, when the activator concentrations are 0.02 and 0.06 , the peaks in the XRD patterns are consistent with the standard PDF card 01-070-3482 $\left(\mathrm{CaMgSi}_{2} \mathrm{O}_{6}\right)$, indicating the successful synthesis of a pure phase of $\mathrm{Ca}_{1-\mathrm{x}} \mathrm{Eu}_{\mathrm{x}} \mathrm{MgSi}_{2} \mathrm{O}_{6}$. The crystallite sizes 
from the TOPAS program were found to be $\sim 16 \mathrm{~nm}, \sim 13 \mathrm{~nm}, \sim 17 \mathrm{~nm}$, and $\sim 10 \mathrm{~nm}$ for $x=$ $0.02,0.06,0.1$, and 0.2 , respectively, indicating that crystallite sizes did not significantly change with $x$ in the current range of activator concentrations due to similarity of ionic radii of $\mathrm{Ca}^{2+}$ and $\mathrm{Eu}^{2+}$.

Figure 6a shows SEM images of the phosphors after post-synthesis annealing at $1350^{\circ} \mathrm{C}$ for $3 \mathrm{~h}$. The particles show agglomeration and form aggregates due to the high temperature during post-synthesis annealing. The morphology of the phosphors after postsynthesis annealing at $1400^{\circ} \mathrm{C}$ for $10 \mathrm{~h}$ is shown in Figure $6 \mathrm{~b}$. The particles are more agglomerated than those in Figure 6a. Figure 6c-f show the SEM images of $\mathrm{Ca}_{1-}$ ${ }_{x} \mathrm{Eu}_{\mathrm{x}} \mathrm{Mg}\left(\mathrm{SiO}_{3}\right)_{2}(x=0.02,0.06,0.1$, and 0.2$)$. It should be noted that the morphology of $\mathrm{Ca}_{1-}$ ${ }_{x} \mathrm{Eu}_{\mathrm{x}} \mathrm{Mg}\left(\mathrm{SiO}_{3}\right)_{2}$ is not altered when $x$ increases.

\section{Photoluminescence spectra, color calculator data and quantum efficiency of synthesized}

\section{phosphors}

Figure 7a shows the PL excitation (PLE, monitored at $511 \mathrm{~nm}$ ) and PL emission (excitation wavelength, $E_{\text {ex }}=350 \mathrm{~nm}$ ) spectra for $\left(\mathrm{Ca}_{0.06} \mathrm{Eu}_{0.04}\right)_{7} \mathrm{Mg}\left(\mathrm{SiO}_{4}\right)_{4}$. The PLE spectra show broadband absorption in the near UV region from 200 to $450 \mathrm{~nm}$, with a maximum at $\sim 350 \mathrm{~nm}$, which arises from the allowed transition of $\mathrm{Eu}^{2+}$. The experimental $\lambda_{\mathrm{ex}}(\sim 350 \mathrm{~nm})$ is very similar to the calculated $\lambda_{\text {ex }}(337 \mathrm{~nm})$, confirming the validity of our approach to discover new phosphor compositions. The PL emission spectrum consists of a broad band centered at $511 \mathrm{~nm}$, which is attributed to the allowed $4 f^{6} 5 d^{1} \rightarrow 4 f^{7}$ transition of $\mathrm{Eu}^{2+}$. The $\Phi$ of $\left(\mathrm{Ca}_{0.96} \mathrm{Eu}_{0.04}\right)_{7} \mathrm{Mg}\left(\mathrm{SiO}_{4}\right)_{4}$ with the post-synthesis annealing conditions of $1100^{\circ} \mathrm{C}$ for $3 \mathrm{~h}$ under air, $1350^{\circ} \mathrm{C}$ for $3 \mathrm{~h}$ under air, and $1400^{\circ} \mathrm{C}$ for $10 \mathrm{~h}$ under air, were $\sim 19 \%, \sim 30 \%$, and $11 \%$, respectively. Generally, $\Phi$ is increased with increase of annealing temperature because of the increase of crystallite sizes [37]. In this work, although the crystallite sizes of the powders calcined at $1400^{\circ} \mathrm{C}$ for $10 \mathrm{~h}$ is slightly larger than the powders calcined at $1100^{\circ} \mathrm{C}$ 
for $3 \mathrm{~h}$ and $1350^{\circ} \mathrm{C}$ for $3 \mathrm{~h}$, the $\Phi$ from the $1400^{\circ} \mathrm{C}$ powders is significantly smaller than that of the $1100^{\circ} \mathrm{C}$ and $1350^{\circ} \mathrm{C}$ powders. This reduction of $\Phi$ can be attributed to aggregation of the phosphors particles. As shown in Figure $6 \mathrm{a}$ and b, the powders calcined at $1400^{\circ} \mathrm{C}$ form more aggregated structure compared to the powders calcined at $1350^{\circ} \mathrm{C}$. Hong et al. [38] and Lenggoro et al. [39] reported that highly aggregated phosphor powders showed a reduction in emission intensity, which is related to $\Phi$. Aggregated powders can possibly have an influence on the reabsorption and light scattering, which results in a reduction of $\Phi[40]$. Thus, non-aggregated powders play an important role for the obtainment of a high $\Phi$. Previously reported $\Phi$ for $\left(\mathrm{Ca}_{1-\mathrm{x}} \mathrm{Eu}_{\mathrm{x} .}\right)_{7} \mathrm{Mg}\left(\mathrm{SiO}_{4}\right)_{4}, 18 \%$ for $x=0.04\left(\lambda_{\mathrm{ex}}=350 \mathrm{~nm}\right)$ [16] and $\sim 23 \%$ for $x=0.02\left(\lambda_{\mathrm{ex}}=400 \mathrm{~nm}\right)$ [17]), synthesized by solid state reaction at $1350^{\circ} \mathrm{C}$ for $3 \mathrm{~h}$ in $\mathrm{N}_{2} / \mathrm{H}_{2}$ at $1100 \sim 1400^{\circ} \mathrm{C}$ for $4 \mathrm{~h}$ in $\mathrm{N}_{2} / \mathrm{H}_{2}$, respectively, were similar to the present results. However, a high $\Phi(\sim 64 \%)$ for $\left(\mathrm{Ca}_{1-\mathrm{x}} \mathrm{Eu}_{\mathrm{x} .}\right)_{7} \mathrm{Mg}\left(\mathrm{SiO}_{4}\right)_{4}$ was previously found for an unusually low activator concentration, $x=0.001\left(\lambda_{\mathrm{ex}}=365 \mathrm{~nm}\right)$ [41]. These powders were formed by a solid-state reaction at $1250^{\circ} \mathrm{C}$ for $6 \mathrm{~h}$ in $\mathrm{N}_{2} / \mathrm{H}_{2}$. Since both the synthesis methodology and post-synthesis calcination, affect the crystallite sizes, the differences between values of $\Phi$ for the present work and for previous reports can be attributed to differences in synthesis method, post-processing temperature, and dopant concentration.

Figure $7 \mathrm{~b}$ shows the PL excitation (PLE, monitored at $458 \mathrm{~nm}$ ) and PL emission (excitation wavelength, $E_{e x}=350 \mathrm{~nm}$ ) for $\mathrm{CaMg}\left(\mathrm{SiO}_{3}\right)_{2}: \mathrm{Eu}^{2+}$. A broad excitation spectrum is observed from $200 \mathrm{~nm}$ to $400 \mathrm{~nm}$, with a maximum at $350 \mathrm{~nm}$, which is a result of the allowed transition of $\mathrm{Eu}^{2+}$. This value is also close to our calculated excitation wavelength of $377 \mathrm{~nm}$. The PL emission shows a spectrum maximum at $458 \mathrm{~nm}$, which is attributed to the parity-allowed $4 f^{6} 5 d^{1} \rightarrow 4 f^{7}$ transition of $\mathrm{Eu}^{2+}$. Solid lines in Figure $7 \mathrm{~b}$ refer to the emission monitored at $350 \mathrm{~nm}$ for various concentrations of $\mathrm{Eu}^{2+}(x=0.02,0.06,0.1$, and 0.2$)$ in $\mathrm{CaMg}\left(\mathrm{SiO}_{3}\right)_{2}$. The emission intensity increases until $x=0.06$ and then decreases due to the 
concentration quenching effect. The $\Phi$ was $\sim 5 \%$ when $x=0.06$ for $\lambda_{\text {ex }}=350 \mathrm{~nm}$, which is the highest quantum efficiency among $x=0.02,0.06,0.1$, and 0.2 . This $\Phi$ is similar to the previously reported value for this material of $\sim 9.1 \%$ [42].

Our results indicate that high structural rigidity, as quantified by high $\Theta$, is not a sufficient condition for high $\Phi$. Both silicates studied in this work have high $\Theta$, but relatively low $\Phi$. For compounds that have similar band gaps and chemistries, $\Theta$ indeed seems to be correlated with $\Phi$. For example, the calculated $\Theta$ 's of X1-Y ${ }_{2} \mathrm{SiO}_{5}$ (GGA band gap, $4.73 \mathrm{eV}$ ) and $\mathrm{X} 2-\mathrm{Y}_{2} \mathrm{SiO}_{5}(\mathrm{GGA}$ band gap, $4.77 \mathrm{eV}$ ) are $491 \mathrm{~K}$ and $512 \mathrm{~K}$ (Table 1) and the $\Phi$ 's are $\sim 36 \%$ and $\sim 45 \%$, respectively, showing that as $\Theta$ increases, $\Phi$ also increases [43]. However, $\Phi$ is also strongly affected by the host band gap. Furthermore, it has been demonstrated that a host with low $\Theta$ yields high $\Phi$ when it is activated with $\mathrm{Eu}^{2+}$. For instance, the computed $\Theta$ 's for $\mathrm{Ba}_{2} \mathrm{SiO}_{4}, \alpha-\mathrm{Sr}_{2} \mathrm{SiO}_{4}$ and $\beta-\mathrm{Sr}_{2} \mathrm{SiO}_{4}$ are $307 \mathrm{~K}, 360 \mathrm{~K}$ and $428 \mathrm{~K}$, respectively, each of which is smaller than the suggested $500 \mathrm{~K}$, whereas the experimentally measured $\Phi$ for $E u^{2+}-$ activated $\mathrm{Ba}_{2} \mathrm{SiO}_{4}$ and $\mathrm{Sr}_{2} \mathrm{SiO}_{4}$ are $>85 \%[37,44]$. These findings suggest that although calculated $\Theta$ may be a starting point, caution should be given to the reliability of $\Theta$ as a descriptor of $\Phi$. Therefore, more efforts need to be devoted to explore more accurate descriptors to screen for phosphors with high $\Phi$.

For $\mathrm{Ca}_{7} \mathrm{Mg}\left(\mathrm{SiO}_{4}\right)_{4}: \mathrm{Eu}^{2+}$, the color represented by the $x, y$ color coordinates $(0.25$, 0.49) is located in the green region of the diagram on the Commission International de I'Eclairage (CIE) diagram. According to the National Television System Committee (NTSC) RGB colors, the values of good green-emitting phosphors are 0.21 and 0.71 [45]. The color coordinates previously reported $(0.20,0.47)$ were for powders produced by a solid state reaction with $x=0.001$ and $\lambda_{\mathrm{ex}}=365 \mathrm{~nm}$ [41]. The discrepancy in these coordinates with the present results can be explained by the difference in $x$ and $\lambda_{\text {ex. }}$ It was previously shown [41] that the coordinates were dependent on both $\lambda_{\mathrm{ex}}$ and $x$ (activator concentration), attributed to 
the three different $\mathrm{Eu}^{2+}$ sites. Emission wavelengths were found to be $455 \mathrm{~nm}\left(\mathrm{Eu}(1)^{2+}\right), 504$ $\mathrm{nm}\left(\operatorname{Eu}(2)^{2+}\right)$, and $540 \mathrm{~nm}\left(\operatorname{Eu}(3)^{2+}\right) . \mathrm{Eu}^{2+}$ will enter in the $\mathrm{Eu}(1)^{2+}$ sites preferentially for small concentrations of $\mathrm{Eu}^{2+}$, which will increase the emission intensity from the $\mathrm{Eu}(1)^{2+}$ sites $(455 \mathrm{~nm})$. When the activator concentration increases, $\mathrm{Eu}^{2+}$ preferentially occupies $\mathrm{Eu}(2)^{2+}$ and $\operatorname{Eu}(3)^{2+}$ sites, which will decrease the emission from the $\mathrm{Eu}(1)^{2+}$ sites. It should be noted that these three emission spectra overlap and display one broad emission peak from $450 \mathrm{~nm}$ to $600 \mathrm{~nm}$. Thus, the width of emission spectra would change, depending on $x$ and $\lambda_{\text {ex }}$.

Despite the slight difference in values of the color coordinates in this work, the obtained values were in the green color range, indicating that $\mathrm{Ca} 7 \mathrm{Mg}\left(\mathrm{SiO}_{4}\right)_{4}: \mathrm{Eu}^{2+}$ is a potential greenemitting phosphor for use in nUV LEDs.

The $x, y$ color coordinates of $\mathrm{Ca}_{0.94} \mathrm{Eu}_{0.06} \mathrm{Mg}\left(\mathrm{SiO}_{3}\right)_{2}$ were 0.14 and 0.05 , located in the blue region on the CIE diagram and the color coordinates of all samples ( $x$ ranging from 0.02 to 0.2 ) are similar. These values are similar to those defined by NTSC CIE for blue color $(0.14,0.08)$, indicating that $\mathrm{CaMg}\left(\mathrm{SiO}_{3}\right)_{2}: \mathrm{Eu}^{2+}$ could be utilized as a blue-emitting phosphor for nUV LEDs.

\section{Concentration quenching of $\mathrm{CaMg}\left(\mathrm{SiO}_{3}\right)_{2}: \mathrm{Eu}^{2+}$}

The concentration quenching behavior was analyzed using the emission intensity change as a function of $x$. Blasse reported that the critical transfer distance $\left(R_{c}\right)$ was defined as: [46]:

$$
R_{c}=2\left(\frac{3 V}{4 \pi x_{c} N}\right)^{1 / 3}
$$

where $x_{c}$ is the critical dopant concentration when the emission intensity shows the maximum value, $V$ is the volume of the unit cell, and $N$ is the number of cations in the unit cell. $R_{c}$ in $\mathrm{CaMg}\left(\mathrm{SiO}_{3}\right)_{2}$ was calculated to be $\sim 1.5 \mathrm{~nm}$ by taking the values of $V, x_{c}$, and $N$ as $0.438 \mathrm{~nm}^{3}$, 
0.06, and 4, respectively, from experimental and analytical evaluations. The interaction type was proposed by Dexter [47] when $x>x_{c}[48,49]$ :

$$
\log \left(\frac{I}{x}\right) \propto-\frac{\theta}{3} \log (x)
$$

where $I$ is the emission intensity and $\theta$ is a function of electric multipolar character.

There are three types of concentration quenching mechanisms that result from electrostatic multipolar interaction: dipole-dipole $(d-d)$, dipole-quadrupole $(d-q)$, and quadrupole-quadrupole $(q-q)$ interactions, corresponding to $\theta=6,8$, and 10 , respectively. The type of interaction can be estimated by plotting $(\log (I / x)$ as a function of $(\log x)$. For $\mathrm{CaMg}\left(\mathrm{SiO}_{3}\right)_{2}: \mathrm{Eu}^{2+}$ with $x=0.06,0.1$, and 0.2 , the concentration quenching mechanism under $350 \mathrm{~nm}$ excitation was found to be $d-q$ interaction $(\theta \sim 8)$, as shown in Figure 8 . These findings are in contradiction with the previously reported $(d-d)$ quenching mechanism for the same material for value of $x_{c}=0.01$, with an excitation wavelength of $147 \mathrm{~nm}$ [50], possibly due to the difference in the excitation wavelength that could affect the emission intensity.

\section{Thermal quenching process of $\left.\mathrm{Ca}_{0.96} \mathrm{Eu}_{0.04}\right)_{7} \mathrm{Mg}\left(\mathrm{SiO}_{4}\right)_{4}$ and $\mathrm{Ca}_{0.94} \mathrm{Eu}_{0.06} \mathrm{Mg}\left(\mathrm{SiO}_{3}\right)_{2}$}

The thermal-quenching process of both phosphors was measured as the decrease of emission intensity as a function of temperature (from $25^{\circ} \mathrm{C}$ to $150^{\circ} \mathrm{C}$ ). The data was then plotted using the following equation to describe thermal quenching of luminescence intensity $I(T)$ with temperature $T[29]$ :

$$
I(T)=\frac{I_{o}}{1+\frac{\Gamma_{0}}{\Gamma_{v}} \exp \left(-\frac{\Delta E}{k T}\right)}
$$

where $I_{0}$ is the initial intensity at $25^{\circ} \mathrm{C}, \Delta E$ is the energy barrier for thermal quenching, $k$ is the Boltzmann's constant, $\Gamma_{0}$ is the attempt rate for thermal quenching at $\mathrm{T}=\infty$, and $\Gamma_{v}$ is the radiative decay rate of the $5 \mathrm{~d}$ state of $\mathrm{Eu}^{2+}$. Here we adopted the $\Gamma_{0}$ and $\Gamma_{v}$ with values of $3 \times$ 
$10^{13} \mathrm{~Hz}$ and $1.1 \times 10^{6} \mathrm{~Hz}$, respectively, in line with estimations in the literature [29]. Figure $9 \mathrm{a}$ and $\mathrm{b}$ show the $\mathrm{PL}$ emission intensity as a function of temperature from $25^{\circ} \mathrm{C}$ to $150^{\circ} \mathrm{C}$, demonstrating that there is a significant quenching of the luminescence over this temperature range. Figure $9 \mathrm{c}$ shows a plot of the relative intensity as a function of temperature for both phosphors. $\Gamma_{0} / \Gamma_{v}$ is $2.7 \times 10^{7}$. The values for average $\Delta E$ were obtained in each temperature. $\Delta E$ were $0.56 \pm 0.03 \mathrm{eV}$ for $\left(\mathrm{Ca}_{0.96} \mathrm{Eu}_{0.04}\right)_{7} \mathrm{Mg}\left(\mathrm{SiO}_{4}\right)_{4}$ and $0.52 \pm 0.02 \mathrm{eV}$ for $\mathrm{Ca}_{0.94} \mathrm{Eu}_{0.06} \mathrm{Mg}\left(\mathrm{SiO}_{3}\right)_{2}$. Note that there are many factors that influence the measured intensity than just thermal quenching alone (e.g. synthesis conditions, particle crystallinity). These factors will also affect the measured curve and subsequently the fitted thermal activation barrier. But we believe the relative trend for both cases is reasonable. These $\Delta E$ values were in good agreement with the range of calculated values of similar calcium compounds (0.2-0.6 eV) [29]. In general, the larger the thermal activation energy, the better $\Phi$ obtained for $\mathrm{Eu}^{2+}-$ activated phosphors. Although the predicted $\Theta$ for $\left(\mathrm{Ca}_{0.96} \mathrm{Eu}_{0.04}\right)_{7} \mathrm{Mg}\left(\mathrm{SiO}_{4}\right)_{4}(601 \mathrm{~K})$ is smaller than $\mathrm{Ca}_{0.94} \mathrm{Eu}_{0.06} \mathrm{Mg}\left(\mathrm{SiO}_{3}\right)_{2}(665 \mathrm{~K})$, the $\Phi$ of $\left(\mathrm{Ca}_{0.96} \mathrm{Eu}_{0.04}\right)_{7} \mathrm{Mg}\left(\mathrm{SiO}_{4}\right)_{4}(30 \%)$ is relative higher than $\mathrm{Ca}_{0.94} \mathrm{Eu}_{0.06} \mathrm{Mg}\left(\mathrm{SiO}_{3}\right)_{2}(5 \%)$, which can be attributed to its larger thermal activation energy.

A simplified relationship between the energy barrier and the quenching temperature $T_{0.5}$ ( the temperature at which the emission intensity declined to $50 \%$ of the low temperature value) was developed by Dorenbos [29] from Eqn. (6):

$$
\Delta E=\frac{T_{0.5}}{680}(\mathrm{eV})
$$

From this equation, the obtained $T_{0.5}$ for $\left(\mathrm{Ca}_{0.96} \mathrm{Eu}_{0.04}\right)_{7} \mathrm{Mg}\left(\mathrm{SiO}_{4}\right)_{4}$ and $\mathrm{Ca}_{0.94} \mathrm{Eu}_{0.06} \mathrm{Mg}\left(\mathrm{SiO}_{3}\right)_{2}$ are $381 \mathrm{~K}$ and $354 \mathrm{~K}$, respectively. These low thermal quenching temperatures suggest that $\Phi$ 's of $\left(\mathrm{Ca}_{0.96} \mathrm{Eu}_{0.04}\right)_{7} \mathrm{Mg}\left(\mathrm{SiO}_{4}\right)_{4}$ and $\mathrm{Ca}_{0.94} \mathrm{Eu}_{0.06} \mathrm{Mg}\left(\mathrm{SiO}_{3}\right)_{2}$ can be severely degraded, even at room temperature. 
Other models of thermal quenching exist. For instance, the thermal ionization model [29] suggests that thermal quenching stability is related to the energy gap between the excited

Eu 5d level and CBM. However, first principles determination of excited states is challenging, though a few recent works have explored this relationship using advanced techniques [51]. For high-throughput screening, a more efficient approximation needs to be developed. For example, the band gap can sometimes be used as a proxy $[12,52]$; the larger the band gap of the host, the more likely that there is a larger gap between the excited 5d level and the CBM (though the exact relationship depends on the magnitude of the Stokes shift). The investigation of these other first principles descriptors will be the subject of future work.

\section{CONCLUSIONS}

An integrated approach of exploring new phosphors for near-UV (nUV) excitation by combining experiments and calculations is outlined. The descriptors of Debye temperature $(\Theta)$ and excitation energy were combined to screen plausible phosphors that are predicted to have high quantum efficiency $(\Phi)$ and can be employed in near-UV emitting LEDs. From the calculation of 27 host materials, $\mathrm{Ca} 7 \mathrm{Mg}\left(\mathrm{SiO}_{4}\right)_{4}$ and $\mathrm{CaMg}\left(\mathrm{SiO}_{3}\right)_{2}$ were selected because predicted $\Theta$ for $\mathrm{Ca} 7 \mathrm{Mg}\left(\mathrm{SiO}_{4}\right)_{4}$ and $\mathrm{CaMg}\left(\mathrm{SiO}_{3}\right)_{2}$ were found to be $601 \mathrm{~K}$ and $665 \mathrm{~K}$, respectively, which are expected to have high $\Phi(>80 \%)$. The predicted and experimental excitation energies are similar. The measured values of $\Phi$ are lower than the expected values, based on high $\Theta$. The main peak in the photoluminescence emission spectra under excitation of $350 \mathrm{~nm}$ is $511 \mathrm{~nm}$ for $\left(\mathrm{Ca}_{0.96} \mathrm{Eu}_{0.04}\right)_{7} \mathrm{Mg}\left(\mathrm{SiO}_{4}\right)_{4}$, with chromaticity coordinates of $(0.25$, 0.49), and $458 \mathrm{~nm}$ for $\mathrm{Ca}_{0.94} \mathrm{Eu}_{0.06} \mathrm{Mg}\left(\mathrm{SiO}_{3}\right)_{2}$ with chromaticity coordinates of $(0.14,0.05)$. The concentration self-quenching mechanism for $\mathrm{CaMg}\left(\mathrm{SiO}_{3}\right)_{2}: \mathrm{Eu}^{2+}$ under $350 \mathrm{~nm}$ is the $d-q$ interaction. The thermal quenching temperatures $\left(T_{0.5}\right)$ are $381 \mathrm{~K}$ and $354 \mathrm{~K}$ for $\left(\mathrm{Ca}_{0.96} \mathrm{Eu}_{0.04}\right)_{7} \mathrm{Mg}\left(\mathrm{SiO}_{4}\right)_{4}$ and $\mathrm{Ca}_{0.94} \mathrm{Eu}_{0.06} \mathrm{Mg}\left(\mathrm{SiO}_{3}\right)_{2}$, respectively, indicating poor thermal stability. Despite having a high $\Theta$, a low $\Phi$ is found for the two candidates. Conversely, other 
screened hosts (e.g. $\mathrm{Ba}_{2} \mathrm{SiO}_{4}: \mathrm{Eu}^{2+}$ ) have low computed $\Theta$, but are known to have a high $\Phi$. Therefore, the use of high $\Theta$ as an indicator for high quantum efficiency should be treated with caution when screening host candidates. It is desirable to develop more well-defined criteria for the screening of host candidates for high $\Phi$ phosphors. The approach developed in this work can be leveraged for the discovery of additional nUV excited phosphors.

\section{ACKNOWLEDGEMENTS}

This work is supported by the National Science Foundation, Ceramics Program Grant DMR1411192. 


\section{REFERENCES}

[1] S. Nakamura, and G. Fasol, The Blue Laser Diode, Berlin: Springer, 1996.

[2] N. Narendran, N. Maliyagoda, A. Bierman, R. M. Pysar, and M. Overington, "Characterizing white LEDs for general illumination applications," Proc. SPIE Int. Soc. Opt. Eng. , vol. 3938, pp. 240-248, 2000.

[3] M. G. Craford, Light Emitting Diode Technology, Dordrecht: Kluwer Academic Publishers, 1996.

[4] H. S. Jang, W. B. Im, D. C. Lee, D. Y. Jeon, and S. S. Kim, "Enhancement of red spectral emission intensity of $\mathrm{Y}_{3} \mathrm{Al}_{5} \mathrm{O}_{12}: \mathrm{Ce}^{3+}$ phosphor via $\mathrm{Pr}$ co-doping and $\mathrm{Tb}$ substitution for the application to white LEDs," Journal of Luminescence, vol. 126, pp. 371-377, 2007.

[5] Y. Q. Li, A. C. A. Delsing, G. de With, and H. T. Hintzen, "Luminescence properties of $\mathrm{Eu}^{2+}$-activated alkaline-earth silicon-oxynitride $\mathrm{MSi}_{2} \mathrm{O}_{2-\delta} \mathrm{N}_{2+2 / 3 \delta}(\mathrm{M}=\mathrm{Ca}, \mathrm{Sr}, \mathrm{Ba})$ : a promising class of novel LED conversion phosphors," Chemistry of Materials, vol. 17, pp. 3242-3248, 2005.

[6] J. K. Sheu, S. J. Chang, C. H. Kuo, Y. K. Su, L. W. Wu, Y. C. Lin, W. C. Lai, J. M. Tsai, G. C. Chi, and R. K. Wu, "White-light emission from near UV InGaN-GaN LED chip precoated with blue/green/red phosphors," IEEE Photonics Technology Letters, vol. 15, pp. 18-20, 2003.

[7] S. Neeraj, N. Kijima, and A. K. Cheetham, "Novel red phosphors for solid-state lighting: the system $\mathrm{NaM}\left(\mathrm{WO}_{4}\right)_{2-\mathrm{x}}\left(\mathrm{MoO}_{4}\right)_{\mathrm{x}}: \mathrm{Eu}^{3+}(\mathrm{M}=\mathrm{Gd}, \mathrm{Y}, \mathrm{Bi}),{ }^{\prime}$ Chemical Physics Letters, vol. 387, pp. 2-6, 2004.

[8] S. H. M. Poort, W. Janssen, and G. Blasse, "Optical properties of Eu ${ }^{2+}$-activated orthosilicates and orthophosphates," Journal of Alloys and Compounds, vol. 260, pp. 93-97, 1997.

[9] Y. Chen, Y. Li, J. Wang, M. Wu, and C. Wang, "Color-Tunable Phosphor of Eu ${ }^{2+}$ and $\mathrm{Mn}^{2+}$ Codoped $\mathrm{Ca}_{2} \mathrm{Sr}\left(\mathrm{PO}_{4}\right)_{2}$ for UV Light-Emitting Diodes," The Journal of Physical Chemistry C, vol. 118, no. 23, pp. 12494-12499, 2014.

[10] Z. Xia, Z. Xu, M. Chen, and Q. Liu, "Recent developments in the new inorganic solid-state LED phosphors," Dalton Trans., 2016.

[11] T. Takeda, N. Hirosaki, S. Funahshi, and R.-J. Xie, "Narrow-band green-emitting phosphor $\mathrm{Ba}_{2} \mathrm{LiSi}_{7} \mathrm{AlN}_{12}: \mathrm{Eu}^{2+}$ with high thermal stability discovered by a single particle diagnosis approach," Chemistry of Materials, vol. 27, no. 17, pp. 5892-5898, 2015.

[12] Z. Wang, I.-H. Chu, F. Zhou, and S. P. Ong, "Electronic structure descriptor for the discovery of narrow-band red-emitting phosphors," Chemistry of Materials, vol. 28, no. 11, pp. 4024-4031, 2016.

[13] P. Dorenbos, "The 5d level positions of the trivalent lanthanides in inorganic compounds," Journal of Luminescence, vol. 91, pp. 155-176, 2000.

[14] P. Dorenbos, "Energy of the first $4 \mathrm{f}^{7} \rightarrow 4 \mathrm{f}^{6} 5 \mathrm{~d}$ transition of $\mathrm{Eu}^{2+}$ in inorganic compounds," Journal of Luminescence, vol. 104, no. 4, pp. 239-260, 2003.

[15] J. Brgoch, S. P. DenBaars, and R. Seshadri, "Proxies from Ab initio calculations for screening efficient $\mathrm{Ce}^{3+}$ phosphor hosts," The Journal of Physical Chemistry C, vol. 117, no. 35, pp. 17955-17959, 2013. 
[16] Y. Jia, H. Qiao, Y. Zheng, N. Guo, and H. You, "Synthesis and photoluminescence properties of $\mathrm{Ce}^{3+}$ and $\mathrm{Eu}^{2+}$-activated $\mathrm{Ca} 7 \mathrm{Mg}\left(\mathrm{SiO}_{4}\right)_{4}$ phosphors for solid state lighting," Phys Chem Chem Phys, vol. 14, no. 10, pp. 3537-3542, Mar 14, 2012.

[17] K. H. Lee, S. H. Park, H. S. Yoon, Y.-I. Kim, H. G. Jang, and W. B. Im, "Bredigitestructure orthosilicate phosphor as a green component for white LED: the structural and optical properties," Optical Express, vol. 20, no. 6, pp. 6248-6259, 2012.

[18] J. McKittrick, M. E. Hannah, A. Piquette, J. K. Han, J. I. Choi, M. Anc, M. Galvez, H. Lugauer, J. B. Talbot, and K. C. Mishra, "Phosphor Selection Considerations for Near-UV LED Solid State Lighting," ECS Journal of Solid State Science and Technology, vol. 2, no. 2, pp. R3119-R3131, 2012.

[19] P. E. Blöchl, "Projector augmented-wave method," Physical Review B, vol. 50, no. 24, pp. 17953-17979, 1994.

[20] G. Kresse, "Efficient iterative schemes for ab initio total-energy calculations using a plane-wave basis set," Physical Review B, vol. 54, pp. 11169-11186, 1996.

[21] J. P. Perdew, K. Burke, and M. Ernzerhof, "Generalized gradient approximation made simple," Physical Review Letters, vol. 77, pp. 3865-3868, 1996.

[22] S. P. Ong, S. Cholia, A. Jain, M. Brafman, D. Gunter, G. Ceder, and K. A. Persson, "The materials application programming interface (API): a simple, flexible and efficient API for materials data based on representational state transfer (REST) principles," Computational Materials Science, vol. 97, pp. 209-215, 2015.

[23] A. Jain, S. P. Ong, G. Hautier, W. Chen, W. D. Richards, S. Dacek, S. Cholia, D. Gunter, D. Skinner, G. Ceder, and K. A. Persson, "Commentary: The materials project: a materials genome approach to accelerating materials innovation," $A P L$ Materials, vol. 1, no. 1, pp. 011002, 2013.

[24] Z. Deng, Z. Wang, I.-H. Chu, J. Luo, and S. P. Ong, "Elastic properties of alkali superionic conductor electrolytes from first principles calculations," Journal of The Electrochemical Society, vol. 163, no. 2, pp. A67-A74, 2015.

[25] A. Chaudhry, R. Boutchko, G. Zhang, N. Grønbech-Jensen, and A. Canning, "Firstprinciples study of luminescence in Ce-doped inorganic scintillators," Physical Review B, vol. 89, pp. 155105, 2014.

[26] F. Tran, and P. Blaha, "Accurate band gaps of semiconductors and insulators with a semilocal exchange-correlation potential," Physical Review Letters, vol. 102, pp. 5-8, 2009.

[27] P. Dorenbos, "Absolute location of lanthanide energy levels and the performance of phosphors," Journal of Luminescence, vol. 122-123, pp. 315-317, 2007.

[28] Z. Zhang, O. M. ten Kate, A. Delsing, E. van der Kolk, P. H. L. Notten, P. Dorenbos, J. Zhao, and H. T. Hintzen, "Photoluminescence properties and energy level locations of $\mathrm{RE}^{3+}(\mathrm{RE}=\mathrm{Pr}, \mathrm{Sm}, \mathrm{Tb}, \mathrm{Tb} / \mathrm{Ce})$ in $\mathrm{CaAlSiN}_{3}$ phosphors," Journal of Materials Chemistry, vol. 22, pp. 9813-9820, 2012.

[29] P. Dorenbos, "Thermal quenching of $\mathrm{Eu}^{2+} 5 \mathrm{~d}-4 \mathrm{f}$ luminescence in inorganic compounds," Journal of Physics: Condensed Matter, vol. 17, pp. 8103-8111, 2005.

[30] A. U. Pawar, A. P. Jadhav, U. Pal, B. K. Kim, and Y. S. Kang, "Blue and red dual emission nanophosphor $\mathrm{CaMgSi}_{2} \mathrm{O}_{6}: \mathrm{Eu}^{\mathrm{n}+}$; crystal structure and electronic configuration," Journal of Luminescence, vol. 132, no. 3, pp. 659-664, 2012.

[31] J. Wang, Y. Huang, X. Wang, L. Qin, and H. J. Seo, "Luminescence properties of Euactivated alkaline and alkaline-earth silicate $\mathrm{Na}_{2} \mathrm{Ca}_{3} \mathrm{Si}_{6} \mathrm{O}_{16}$," Materials Research Bulletin, vol. 55, pp. 126-130, 2014.

[32] R. D. Shannon, "Revised effective ionic radii and systematic studies of interatomie distances in halides and chaleogenides," Acta Crystallographica Section A: Crystal 
Physics, Diffraction, Theoretical and General Crystallography, vol. 32, pp. 751-767, 1976.

[33] K. Momma, and F. Izumi, "VESTA 3 for three-dimensional visualization of crystal, volumetric and morphology data," Journal of Applied Crystallography, vol. 44, no. 6, pp. 1272-1276, 2011.

[34] P. B. Moore, and T. Araki, "The crystal structure of bredigite and genealogy of some alkaline earth orthosilicates," American Mineralogist, vol. 61, pp. 74-87, 1976.

[35] L. Levien, and C. T. Prewitt, "High-pressure structural study of diopside," American Mineralogist, vol. 66, pp. 315-323, 1981.

[36] W.-N. Wang, W. Widiyastuti, T. Ogi, I. W. Lenggoro, and K. Okuyama, "Correlations between crystallite/particle size and photoluminescence properties of submicrometer phosphors," Chem. Mater., vol. 19, pp. 1723-1730, 2007.

[37] J. K. Han, M. E. Hannah, A. Piquette, J. B. Talbot, K. C. Mishra, and J. McKittrick, "Nano- and submicron sized europium activated silicate phosphors prepared by a modified co-precipitation method," ECS Journal of Solid State Science and Technology, vol. 1, no. 3, pp. R98-R102, 2012.

[38] G. Y. Hong, B. S. Jeon, Y. K. Yoo, and J. S. Yoo, "Photoluminescence Characteristics of Spherical $\mathrm{Y}_{2} \mathrm{O}_{3}$ :Eu Phosphors by Aerosol Pyrolysis," Journal of The Electrochemical Society, vol. 148, no. 11, pp. H161, 2001.

[39] I. W. Lenggoro, Y. Itoh, K. Okuyama, and T. O. Kim, "Nanoparticles of a doped oxide phosphor prepared by direct-spray pyrolysis," Journal of Materials Research, vol. 19, no. 12, pp. 3534-3539, 2011.

[40] S. Jun, J. Lee, and E. Jang, "Highly luminescent and photostable quantum dot silica monolith and its application to light-emitting diodes," ACS Nano, vol. 7, pp. 14721477, 2013.

[41] J. Zhang, and C. Jiang, "Luminescence properties of $\mathrm{Ca}_{14} \mathrm{Mg}_{2}\left(\mathrm{SiO}_{4}\right)_{8}: \mathrm{Eu}^{2+}$ from various $\mathrm{Eu}^{2+}$ sites for white-light-emitting diodes," Materials Research Bulletin, vol. 60, pp. 467-473, 2014.

[42] A. Pawar, A. Jadhav, C. W. Kim, H. G. Cha, U. Pal, and Y. S. Kang, "Emission controlled dual emitting Eu-doped $\mathrm{CaMgSi}_{2} \mathrm{O}_{6}$ nanophosphors," Journal of Luminescence, vol. 157, pp. 131-136, Jan, 2015.

[43] D. Cervantes-Vasquez, O. E. Contreras, and G. A. Hirata, "Quantum efficiency of silica-coated rare-earth doped yttrium silicate," Journal of Luminescence, vol. 143, pp. 226-232, Nov, 2013.

[44] J. K. Han, M. E. Hannah, A. Piquette, G. A. Hirata, J. B. Talbot, K. C. Mishra, and J. McKittrick, "Structure dependent luminescence characterization of green-yellow emitting $\mathrm{Sr}_{2} \mathrm{SiO}_{4}$ :Eu ${ }^{2+}$ phosphors for near UV LEDs," Journal of Luminescence, vol. 132, no. 1, pp. 106-109, 2012.

[45] J. H. Oh, S. J. Yang, Y.-G. Sung, and Y. R. Do, "Improved color coordinates of green monochromatic pc-LED capped with a band-pass filter," Optical Express, vol. 21, no. 4, pp. 4539-4550, 2013.

[46] G. Blasse, "Energy transfer betwen inequivalent Eu ${ }^{2+}$ ions," Journal of Solid State Chemistry, vol. 62, pp. 207-211, 1986.

[47] D. L. Dexter, "A Theory of Sensitized Luminescence in Solids," The Journal of Chemical Physics, vol. 21, no. 5, pp. 836, 1953.

[48] L. G. V. Uitert, "Characterization of energy transfer interactions between rare earth ions," Journal of Electochem. Soc., vol. 114, pp. 1048-1053, 1967.

[49] L. Ozawa, and P. M. Jaffe, "The mechanism of the emission color shift with activator concentration in $\mathrm{Eu}^{3+}$ activated phosphors," J. Electrochem. Soc., vol. 118, pp. 16781679, 1971. 
[50] W. B. Im, Y.-I. Kim, J. H. Kang, D. Y. Jeon, H. K. Jung, and K. Y. Jung, "Neutron rietveld analysis for optimized $\mathrm{CaMgSi}_{2} \mathrm{O}_{6}: \mathrm{Eu}^{2+}$ and its luminescent properties," Journal of Materials Research, vol. 20, no. 08, pp. 2061-2066, 2005.

[51] S. Poncé, Y. Jia, M. Giantomassi, M. Mikami, and X. Gonze, "Understanding thermal quenching of photoluminescence in oxynitride phosphors from first principles," The Journal of Physical Chemistry C, vol. 120, pp. 4040-4047, 2016.

[52] L. Chen, X. Chen, F. Liu, H. Chen, H. Wang, E. Zhao, Y. Jiang, T. S. Chan, C. H. Wang, W. Zhang, Y. Wang, and S. Chen, "Charge deformation and orbital hybridization: intrinsic mechanisms on tunable chromaticity of $\mathrm{Y}_{3} \mathrm{Al}_{5} \mathrm{O}_{12}: \mathrm{Ce}^{3+}$ luminescence by doping $\mathrm{Gd}^{3+}$ for warm white LEDs," Sci Rep, vol. 5, pp. 11514, 2015. 


\section{LIST OF TABLE AND FIGURE CAPTIONS}

Table 1. Calculated Debye temperature $(\Theta)$ of 27 identified host for $\mathrm{Ce}^{3+}$ or $\mathrm{Eu}^{2+}$ activation. The compositions in bold have $\Theta>500 \mathrm{~K}$. The excitation energy $\left(E_{e x}\right)$ and emission energy $\left(E_{\text {em }}\right)$ were selected from $[13,14,16-18,37,44]$.

Figure 1. Schematic diagram of $4 f \rightarrow 5 d$ transition in $\mathrm{Ce}^{3+}$ or $\mathrm{Eu}^{2+}$ activated phosphors. $E_{\mathrm{g}}, E_{\mathrm{ex}}$ and $E_{4 \mathrm{f}-\mathrm{VBM}}$ denote the band gap of host material, excitation energy, and $4 f$-VBM energy gap, respectively.

Figure 2. The band structure of the host material $\mathrm{Ca}_{7} \mathrm{Mg}\left(\mathrm{SiO}_{4}\right)_{4}$ (a) and $\mathrm{CaMgSi}_{2} \mathrm{O}_{6}$ (b), where it has a direct $\Gamma \rightarrow \Gamma$ transition band gap of $6.86 \mathrm{eV}$ and $7.08 \mathrm{eV}$, respectively.

Figure 3. The orbital-projected density of state (DOS) of $\mathrm{Ca}_{7} \mathrm{Mg}\left(\mathrm{SiO}_{4}\right)_{4}: \mathrm{Eu}^{2+}(\mathrm{a})$, and $\mathrm{CaMgSi}_{2} \mathrm{O}_{6}: \mathrm{Eu}^{2+}(\mathrm{b})$, where the $4 f-\mathrm{VMB}$ energy gap is $3.18 \mathrm{eV}$ and $3.79 \mathrm{eV}$, respectively. The Fermi level is set to 0 .

Figure 4. Unit cell representation of the crystal structure of (a) $\mathrm{Ca}_{7} \mathrm{Mg}\left(\mathrm{SiO}_{4}\right)_{4}: \mathrm{Eu}^{2+}$ (b) $\mathrm{CaMgSi}_{2} \mathrm{O}_{6}: \mathrm{Eu}^{2+}$ drawn with VESTA [33]. $\mathrm{Ca}_{7} \mathrm{Mg}\left(\mathrm{SiO}_{4}\right)_{4}$ has an orthorhombic structure with space group Pnn2 with lattice constants $a=0.6742 \mathrm{~nm}, b=1.0887 \mathrm{~nm}, c=1.8339 \mathrm{~nm}$. $\mathrm{CaMg}\left(\mathrm{SiO}_{3}\right)_{4}$ has an monoclinic structure with space group $C 2 / c$ with lattice constants $a=$ $0.9743 \mathrm{~nm}, b=0.8879 \mathrm{~nm}, c=0.5230 \mathrm{~nm}$. Both lattice parameters are calculated using TOPAS.

Figure 5. X-ray diffraction patterns: (a) $\left(\mathrm{Ca}_{0.96} \mathrm{Eu}_{0.04}\right)_{7} \mathrm{Mg}\left(\mathrm{SiO}_{4}\right)_{4}$ prepared by the solgel/Pechini method with post-synthesis annealing conditions of $1100^{\circ} \mathrm{C}$ or $1350^{\circ} \mathrm{C}$ for $3 \mathrm{~h}$ or $1400{ }^{\circ} \mathrm{C}$ for 10 h. (b) $\mathrm{Ca}_{1-\mathrm{x}} \mathrm{Eu}_{\mathrm{x}} \mathrm{MgSi}_{2} \mathrm{O}_{6}(x=0.02,0.06,0.1$, and 0.2$)$ prepared by the coprecipitation method with post-synthesis annealing condition of $1100^{\circ} \mathrm{C}$ for $2 \mathrm{~h}$.

Figure 6. Scanning electron micrographs of the powders. $\mathrm{Ca}_{0.96} \mathrm{Eu}_{0.04} \mathrm{Mg}\left(\mathrm{SiO}_{4}\right)_{4}$ after postsynthesis annealing at: (a) $1350^{\circ} \mathrm{C}$ for $3 \mathrm{~h}$ and (b) $1400^{\circ} \mathrm{C}$ for $10 \mathrm{~h} . \mathrm{Ca}_{1-\mathrm{x}} \mathrm{Eu}_{\mathrm{x}} \mathrm{MgSi}_{2} \mathrm{O}_{6}$ with post-synthesis annealing condition of $1100^{\circ} \mathrm{C}$ for $2 \mathrm{~h}$ : (c) $x=0.02$ (d) $x=0.06$, (e) $x=0.10$ and (f) $x=0.20$.

Figure 7. (a) Photoluminescence excitation (dashed line monitored at $511 \mathrm{~nm}$ ) and emission (solid line, $\lambda_{\text {ex }}=350 \mathrm{~nm}$ ) spectra of $\left(\mathrm{Ca}_{0.96} \mathrm{Eu}_{0.04}\right)_{7} \mathrm{Mg}\left(\mathrm{SiO}_{4}\right)$. Blue lines = post-synthesis annealing at $1350^{\circ} \mathrm{C}$ for $3 \mathrm{~h}$ and the red lines $=$ post-synthesis annealing at $1400^{\circ} \mathrm{C}$ for $10 \mathrm{~h}$. Both powders were subsequently heated to $1100^{\circ} \mathrm{C}$ for $4 \mathrm{~h}$ in a reducing atmosphere. (b) Photoluminescence excitation (dashed line monitored at $458 \mathrm{~nm}$ ) and emission (solid line, $\lambda_{\mathrm{ex}}$ $=350 \mathrm{~nm}$ ) spectra of $\mathrm{Ca}_{1-\mathrm{x}} \mathrm{Eu}_{\mathrm{x}} \mathrm{MgSi}_{2} \mathrm{O}_{6}, x=0.02,0.06,0.1$, and 0.2. Post-synthesis annealing condition was $1100^{\circ} \mathrm{C}$ for $2 \mathrm{~h}$. The inset photographs are the phosphor powders excited with $365 \mathrm{~nm} . \Phi=$ quantum efficiency.

Figure 8. The relationship between the $\log (I / x)$ and $\log (x)$ of $\mathrm{Ca}_{1-\mathrm{x}} \mathrm{Eu}_{\mathrm{x}} \mathrm{MgSi}_{2} \mathrm{O}_{6} . I=$ emission intensity, and $x=$ concentration of $\mathrm{Eu}^{2+}(x=0.06,0.1$, and 0.2$)$. 
Figure 9. The emission intensity $(I)$ of the photoluminescence spectra as a function of temperature for (a) $\left(\mathrm{Ca}_{0.96} \mathrm{Eu}_{0.04}\right)_{7} \mathrm{Mg}\left(\mathrm{SiO}_{4}\right)_{4}$, (b) $\mathrm{Ca}_{0.94} \mathrm{Eu}_{0.06} \mathrm{Mg}\left(\mathrm{SiO}_{3}\right)_{2}$. (c) Plot of the relative intensity as a function of temperature from the data in (a) and (b). $\Delta E=$ activation energy and $\Gamma_{0}$ is the attempt rate for thermal quenching at $\mathrm{T}=\infty$, and $\Gamma_{v}$ is the radiative decay rate of the $5 \mathrm{~d}$ state of $\mathrm{Eu}^{2+}$. 
Table 1. Calculated Debye temperature $(\Theta)$ of 27 identified host for $\mathrm{Ce}^{3+}$ or $\mathrm{Eu}^{2+}$ activation. The compositions in bold have $\Theta>500 \mathrm{~K}$. The excitation energy $\left(E_{e x}\right)$ and emission energy $\left(E_{e m}\right)$ were selected from $[13,14,16-18,37,44]$.

\begin{tabular}{|c|c|c|c|}
\hline Host material & $E_{e x}(\mathbf{n m})$ & $E_{e m}(\mathbf{n m})$ & $\boldsymbol{\Theta}(\mathbf{K})$ \\
\hline $\mathrm{Mg}_{2} \mathrm{SiO}_{4}: \mathrm{Ce}^{3+}$ & 373 & 432 & 734 \\
\hline $\mathrm{X1}-\mathrm{YSiO}_{2} \mathrm{~N}: \mathrm{Ce}^{3+}$ & - & - & 695 \\
\hline $\mathrm{CaMg}\left(\mathrm{SiO}_{3}\right)_{2}: \mathrm{Eu}^{2+}$ & 365 & 450 & 665 \\
\hline $\mathrm{Mg}_{3} \mathrm{~F}_{3} \mathrm{BO}_{3}: \mathrm{Ce}^{3+}$ & 399 & 474 & 615 \\
\hline $\mathrm{X2}-\mathrm{YSiO}_{2} \mathrm{~N}: \mathrm{Ce}^{3+}$ & 370 & 405 & 606 \\
\hline $\mathrm{Ca}_{7} \mathrm{Mg}\left(\mathrm{SiO}_{4}\right)_{4}: \mathrm{Eu}^{2+}$ & 350 & $505-520$ & 601 \\
\hline $\mathrm{X}_{2}-\mathrm{Y}_{2} \mathrm{SiO}_{5}: \mathrm{Ce}^{3+}$ & 381 & 480 & 512 \\
\hline $\mathrm{X} 1-\mathrm{Y}_{2} \mathrm{SiO}_{5}: \mathrm{Ce}^{3+}$ & 365 & 430 & 491 \\
\hline $\mathrm{SrY}_{2} \mathrm{O}_{4}: \mathrm{Ce}^{3+}$ & 397 & 560 & 465 \\
\hline $\mathrm{La}_{2} \mathrm{Be}_{2} \mathrm{O}_{5}: \mathrm{Ce}^{3+}$ & 365 & 445 & 464 \\
\hline$\beta-\mathrm{Sr}_{2} \mathrm{SiO}_{4}$ & 310 & $\sim 543$ & 428 \\
\hline $\mathrm{LuBO}_{3}$ (vaterite) $: \mathrm{Ce}^{3+}$ & 365 & 388 & 423 \\
\hline $\mathrm{Ba}_{3} \mathrm{Mg}\left(\mathrm{SiO}_{4}\right)_{2}: \mathrm{Eu}^{2+}$ & 410 & 438 & 422 \\
\hline $\mathrm{X} 2-\mathrm{Lu}_{2} \mathrm{SiO}_{5}: \mathrm{Ce}^{3+}$ & 376 & 462 & 416 \\
\hline $\mathrm{X} 1-\mathrm{Sr}_{2} \mathrm{SiO}_{4}: \mathrm{Eu}^{2+}$ & 390 & 490 & 410 \\
\hline $\mathrm{NaF}: \mathrm{Ce}^{3+}$ & 390 & 472 & 387 \\
\hline $\mathrm{CaAl}_{2} \mathrm{~S}_{4}: \mathrm{Ce}^{3+}$ & 396 & 440 & 373 \\
\hline$\alpha-\mathrm{Sr}_{2} \mathrm{SiO}_{4}$ & 310 & 573 & 360 \\
\hline $\mathrm{Sr}_{2} \mathrm{SiCl}_{2} \mathrm{O}_{3}: \mathrm{Eu}^{2+}$ & 410 & 490 & 349 \\
\hline $\mathrm{SrAl}_{2} \mathrm{~S}_{4}: \mathrm{Ce}^{3+}$ & 397 & 462 & 338 \\
\hline $\mathrm{BaAl}_{2} \mathrm{~S}_{4}: \mathrm{Ce}^{3+}$ & 384 & 444 & 331 \\
\hline $\mathrm{ThO}_{2}: \mathrm{Ce}^{3+}$ & 408 & - & 319 \\
\hline $\mathrm{Ba}_{2} \mathrm{SiO}_{4}$ & 360 & 512 & 307 \\
\hline $\mathrm{Ba}_{2} \mathrm{YB}_{2} \mathrm{O}_{62} \mathrm{Cl}: \mathrm{Ce}^{3+}$ & 370 & 466 & 300 \\
\hline $\mathrm{Ba}_{2} \mathrm{LuB}_{2} \mathrm{O}_{6} \mathrm{Cl}: \mathrm{Ce}^{3+}$ & 370 & 466 & 294 \\
\hline $\mathrm{La}_{3} \mathrm{Si}_{2} \mathrm{~S}_{8} \mathrm{I}: \mathrm{Ce}^{3+}$ & 370 & 446 & 262 \\
\hline $\mathrm{LaOI}: \mathrm{Ce}^{3+}$ & 385 & 435 & 161 \\
\hline
\end{tabular}




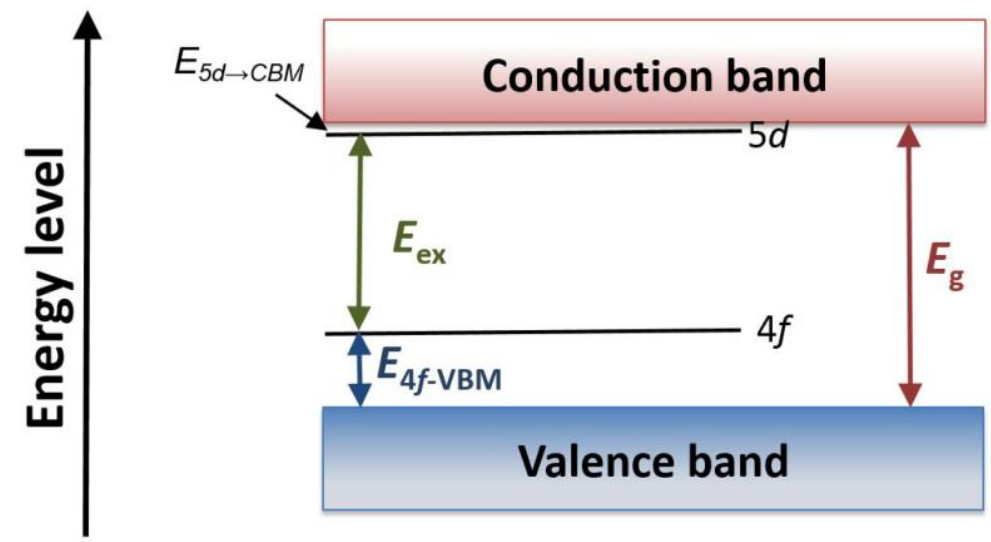

Figure 1. Schematic diagram of $4 f \rightarrow 5 d$ transition in $\mathrm{Ce}^{3+}$ or $\mathrm{Eu}^{2+}$ activated phosphors. $E_{\mathrm{g}}, E_{\mathrm{ex}}$ and $E_{4 \mathrm{f}-\mathrm{VBM}}$ denote the band gap of host material, excitation energy, and $4 f$-VBM energy gap, respectively. 


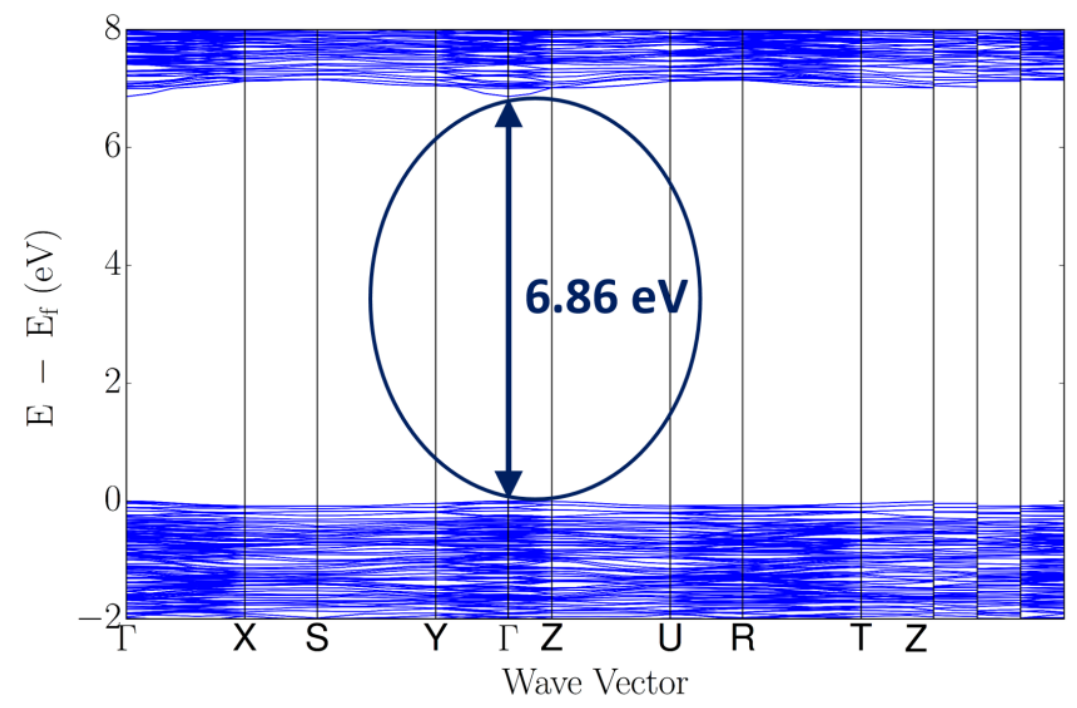

(a)

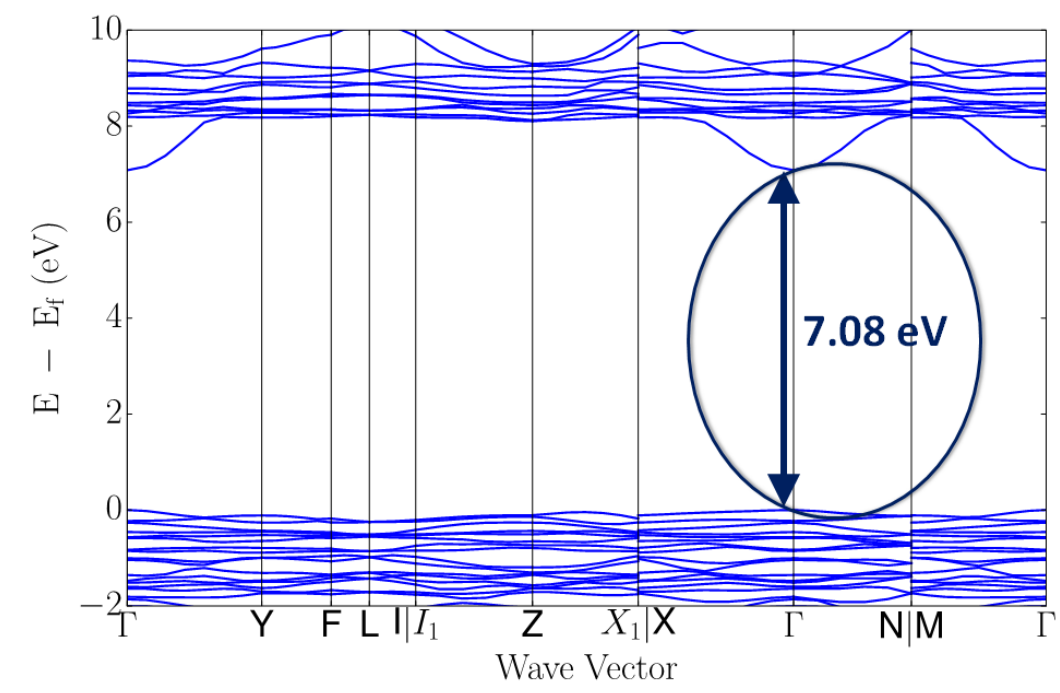

(b)

Figure 2. The band structure of the host material $\mathrm{Ca}_{7} \mathrm{Mg}\left(\mathrm{SiO}_{4}\right)_{4}$ (a) and $\mathrm{CaMgSi}_{2} \mathrm{O}_{6}$ (b), where it has a direct $\Gamma \rightarrow \Gamma$ transition band gap of $6.86 \mathrm{eV}$ and $7.08 \mathrm{eV}$, respectively. 


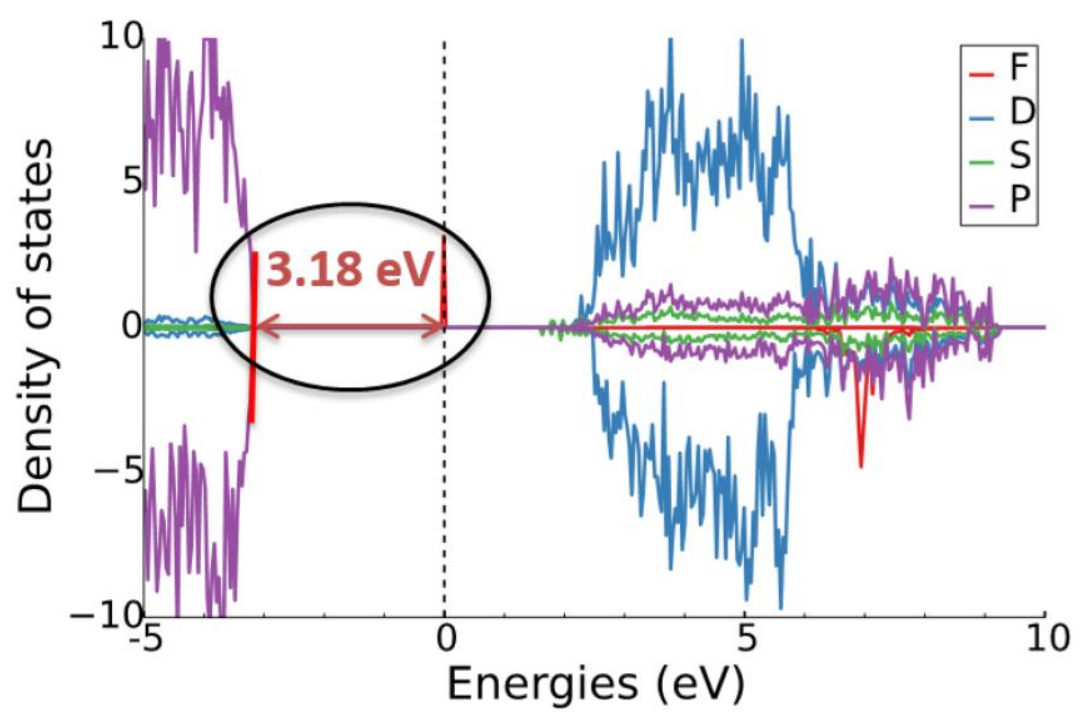

(a)

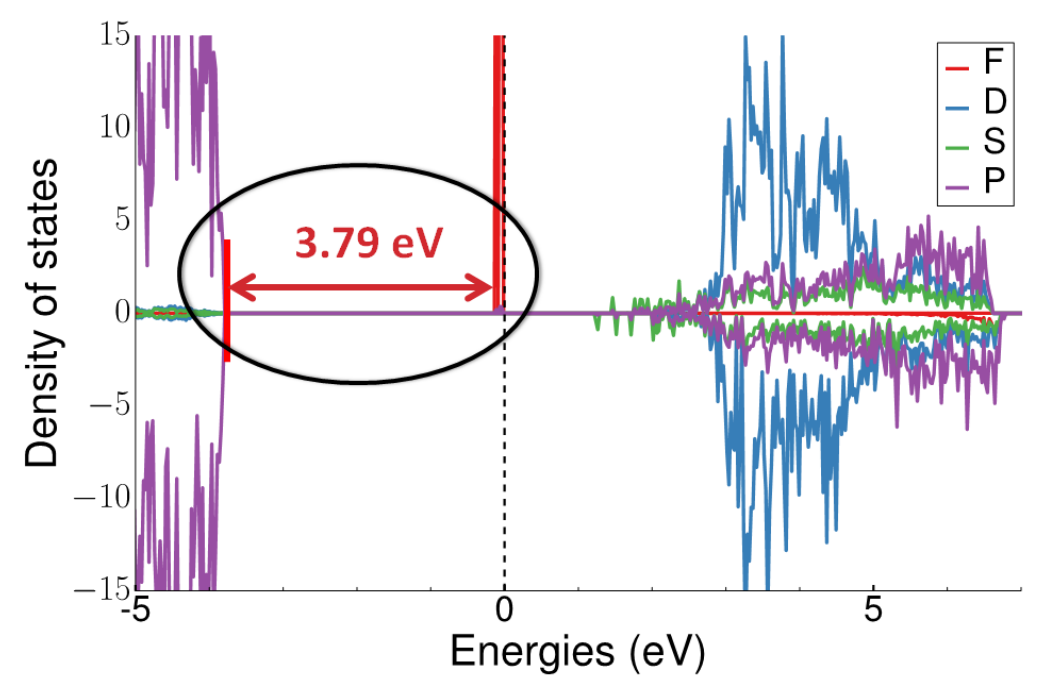

(b)

Figure 3. The orbital-projected density of state (DOS) of $\mathrm{Ca}_{7} \mathrm{Mg}\left(\mathrm{SiO}_{4}\right)_{4}: \mathrm{Eu}^{2+}(\mathrm{a})$, and $\mathrm{CaMgSi}_{2} \mathrm{O}_{6}: \mathrm{Eu}^{2+}(\mathrm{b})$, where the $4 f-\mathrm{VMB}$ energy gap is $3.18 \mathrm{eV}$ and $3.79 \mathrm{eV}$, respectively. The Fermi level is set to 0 . 


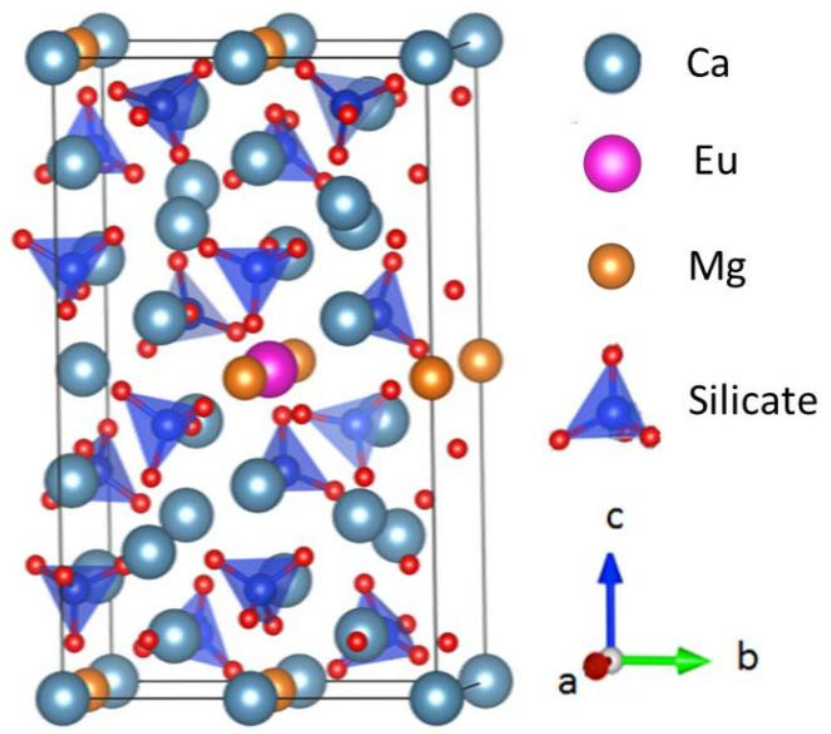

(a)
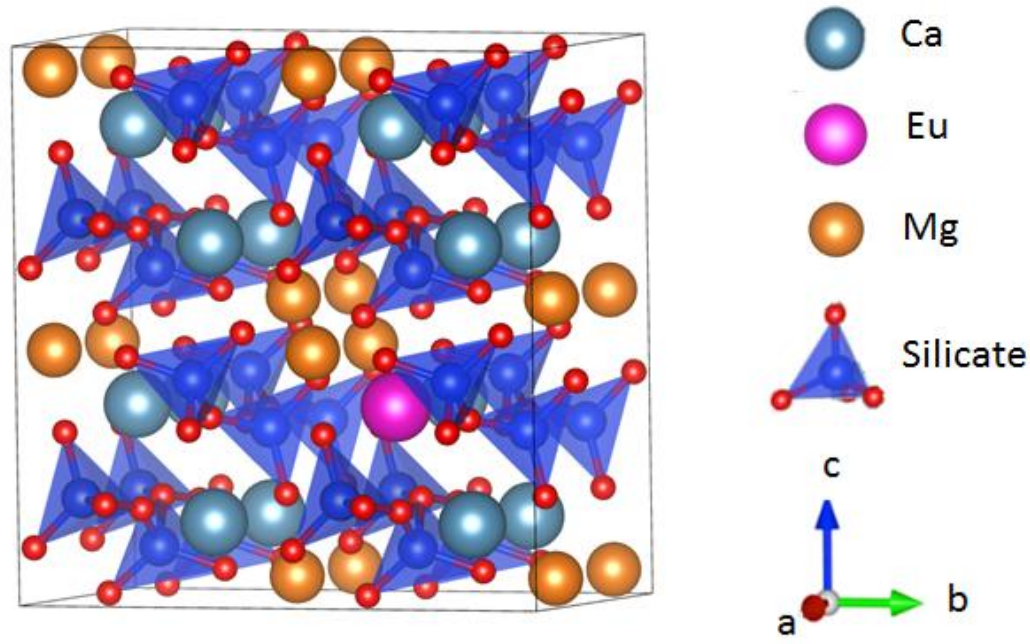

(b)

Figure 4. Unit cell representation of the crystal structure of (a) $\mathrm{Ca} 7 \mathrm{Mg}\left(\mathrm{SiO}_{4}\right)_{4}: \mathrm{Eu}^{2+}$ (b) $\mathrm{CaMgSi}_{2} \mathrm{O}_{6}: \mathrm{Eu}^{2+}$ drawn with VESTA [33]. $\mathrm{Ca} 7 \mathrm{Mg}\left(\mathrm{SiO}_{4}\right)_{4}$ has an orthorhombic structure with space group Pnn2 with lattice constants $a=0.6742 \mathrm{~nm}, b=1.0887 \mathrm{~nm}, c=1.8339 \mathrm{~nm}$.

$\mathrm{Ca} 7 \mathrm{Mg}\left(\mathrm{SiO}_{4}\right)_{4}$ has a monoclinic structure with space group $C 2 / c$ with lattice constants $a=$ $0.9743 \mathrm{~nm}, b=0.8879 \mathrm{~nm}, c=0.5230 \mathrm{~nm}$. Both sets of lattice parameters were calculated using TOPAS. 


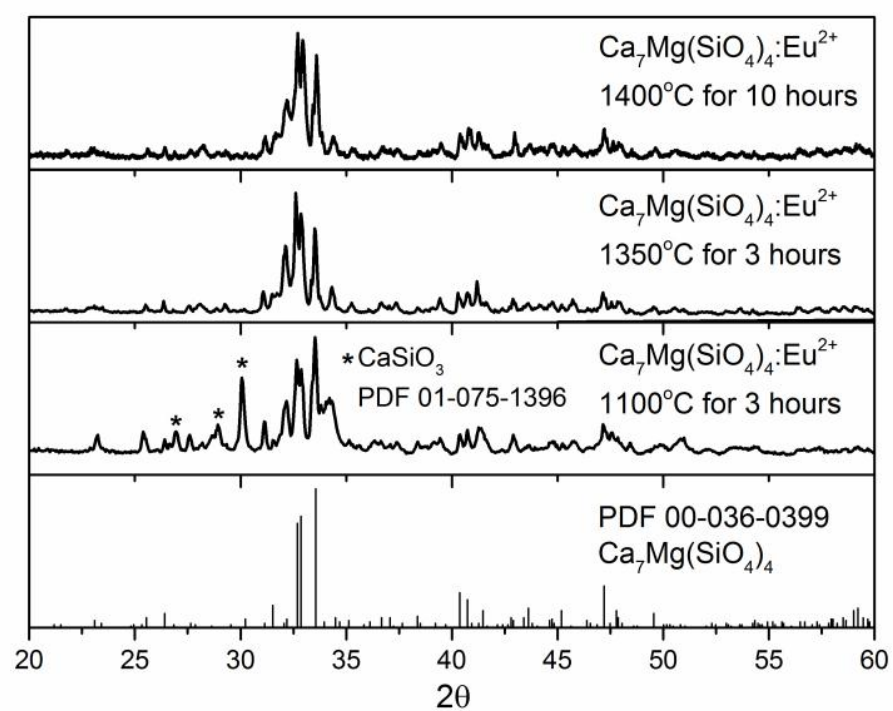

(a)

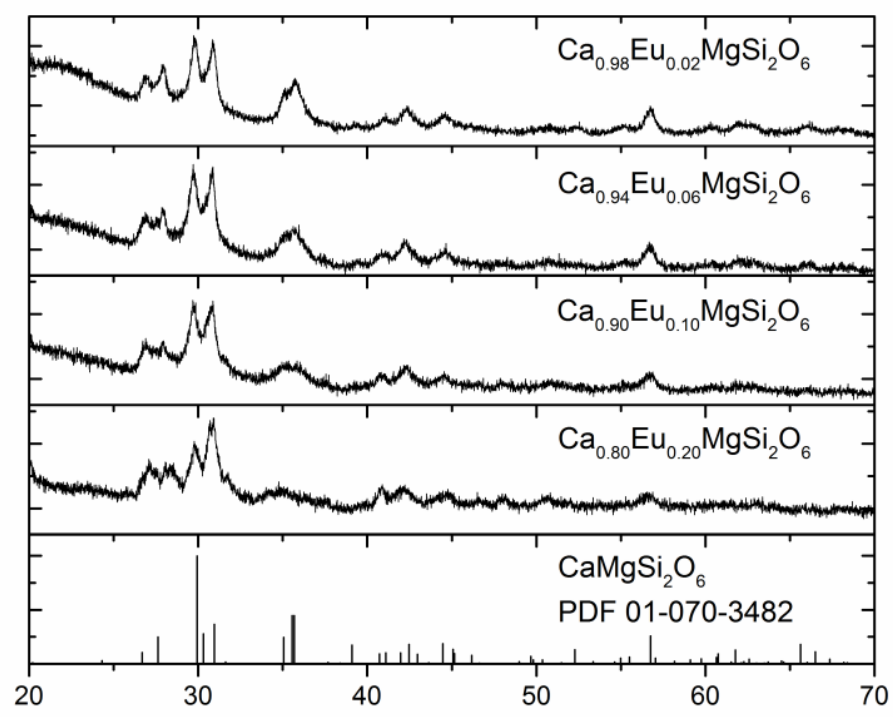

(b)

Figure 5. X-ray diffraction patterns: (a) $\left(\mathrm{Ca}_{0.96} \mathrm{Eu}_{0.04}\right)_{7} \mathrm{Mg}\left(\mathrm{SiO}_{4}\right)_{4}$ prepared by the solgel/Pechini method with post-synthesis annealing conditions of $1100^{\circ} \mathrm{C}$ or $1350^{\circ} \mathrm{C}$ for $3 \mathrm{~h}$ or $1400^{\circ} \mathrm{C}$ for $10 \mathrm{~h}$. (b) $\mathrm{Ca}_{1-\mathrm{x}} \mathrm{Eu}_{\mathrm{x}} \mathrm{MgSi}_{2} \mathrm{O}_{6}(x=0.02,0.06,0.1$, and 0.2$)$ prepared by the coprecipitation method with post-synthesis annealing condition of $1100^{\circ} \mathrm{C}$ for $2 \mathrm{~h}$. 


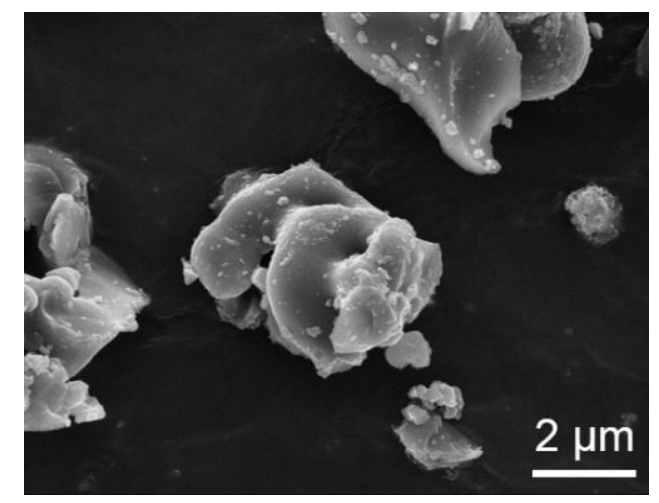

(a)

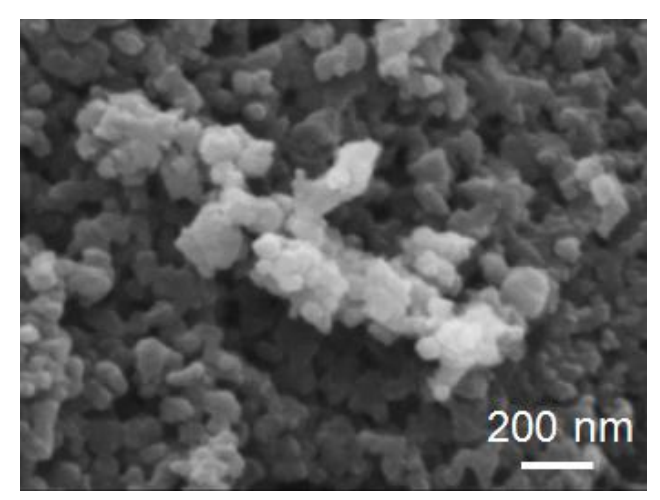

(c)

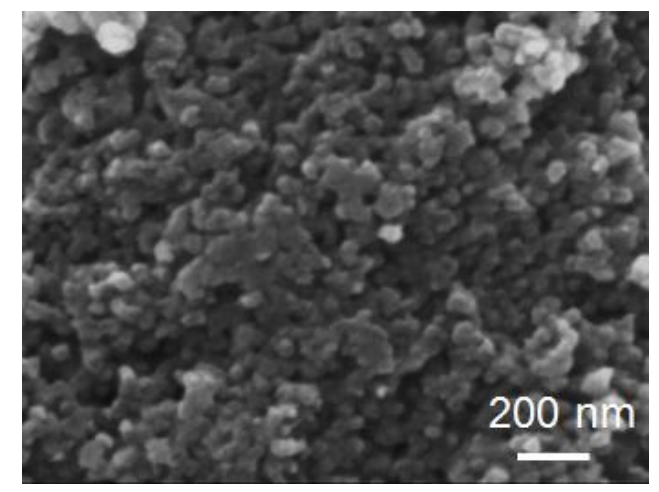

(e)

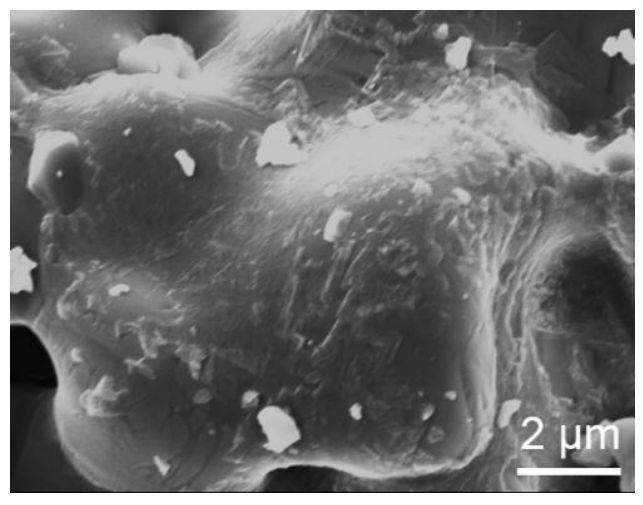

(b)

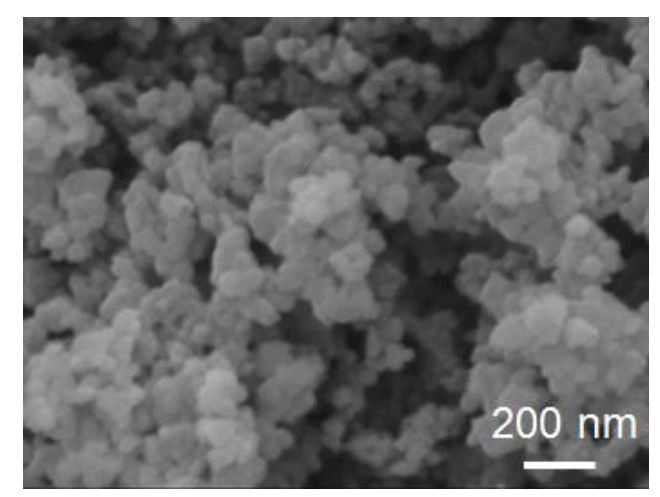

(d)

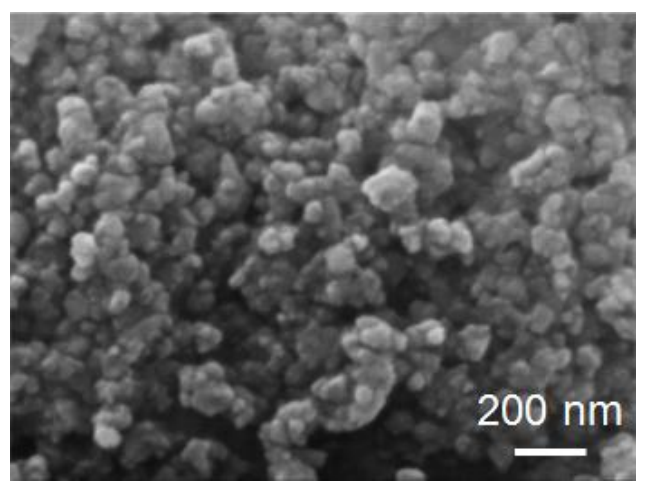

(f)

Figure 6. Scanning electron micrographs of the powders. $\mathrm{Ca}_{0.96} \mathrm{Eu}_{0.04} \mathrm{Mg}\left(\mathrm{SiO}_{4}\right)_{4}$ after postsynthesis annealing at: (a) $1350^{\circ} \mathrm{C}$ for $3 \mathrm{~h}$ and (b) $1400^{\circ} \mathrm{C}$ for $10 \mathrm{~h} . \mathrm{Ca}_{1-\mathrm{x}} \mathrm{Eu}_{\mathrm{x}} \mathrm{MgSi}_{2} \mathrm{O}_{6}$ with post-synthesis annealing condition of $1100^{\circ} \mathrm{C}$ for $2 \mathrm{~h}$ : (c) $x=0.02$ (d) $x=0.06$, (e) $x=0.10$ and (f) $x=0.20$. 


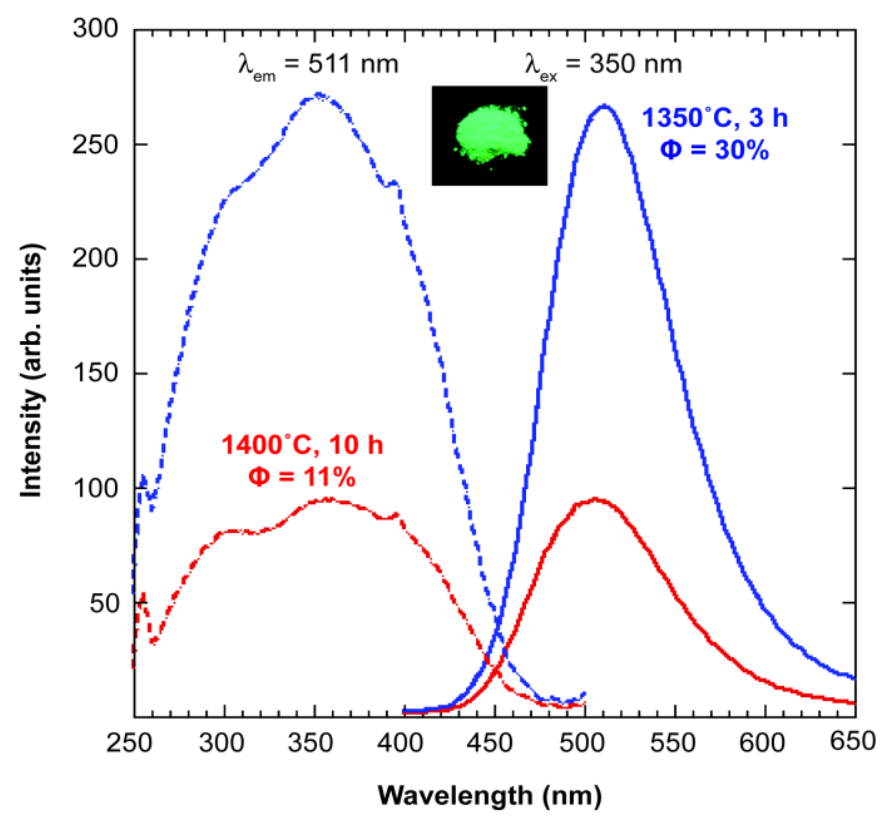

(a)

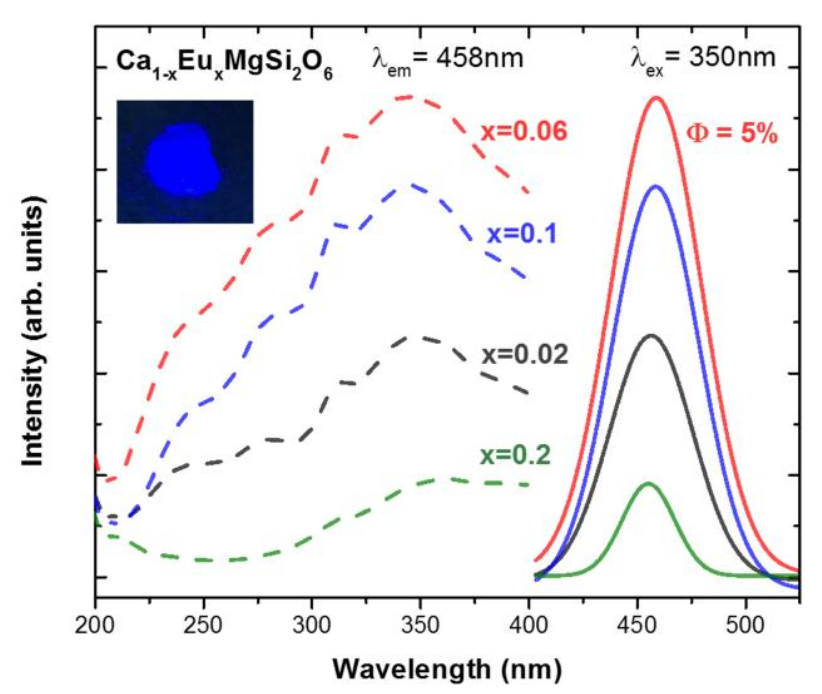

(b)

Figure 7. (a) Photoluminescence excitation (dashed line monitored at $511 \mathrm{~nm}$ ) and emission (solid line, $\lambda_{\text {ex }}=350 \mathrm{~nm}$ ) spectra of $\left(\mathrm{Ca}_{0.96} \mathrm{Eu}_{0.04}\right)_{7} \mathrm{Mg}\left(\mathrm{SiO}_{4}\right)$. Blue lines = post-synthesis annealing at $1350^{\circ} \mathrm{C}$ for $3 \mathrm{~h}$ and the red lines $=$ post-synthesis annealing at $1400^{\circ} \mathrm{C}$ for $10 \mathrm{~h}$. Both powders were subsequently heated to $1100^{\circ} \mathrm{C}$ for $4 \mathrm{~h}$ in a reducing atmosphere. (b) Photoluminescence excitation (dashed line monitored at $458 \mathrm{~nm}$ ) and emission (solid line, $\lambda_{\text {ex }}$ $=350 \mathrm{~nm}$ ) spectra of $\mathrm{Ca}_{1-\mathrm{x}} \mathrm{Eu}_{\mathrm{x}} \mathrm{MgSi}_{2} \mathrm{O}_{6}, x=0.02,0.06,0.1$, and 0.2. Post-synthesis annealing condition was $1100^{\circ} \mathrm{C}$ for $2 \mathrm{~h}$. The inset photographs are the phosphor powders excited with $365 \mathrm{~nm} . \Phi=$ quantum efficiency. 


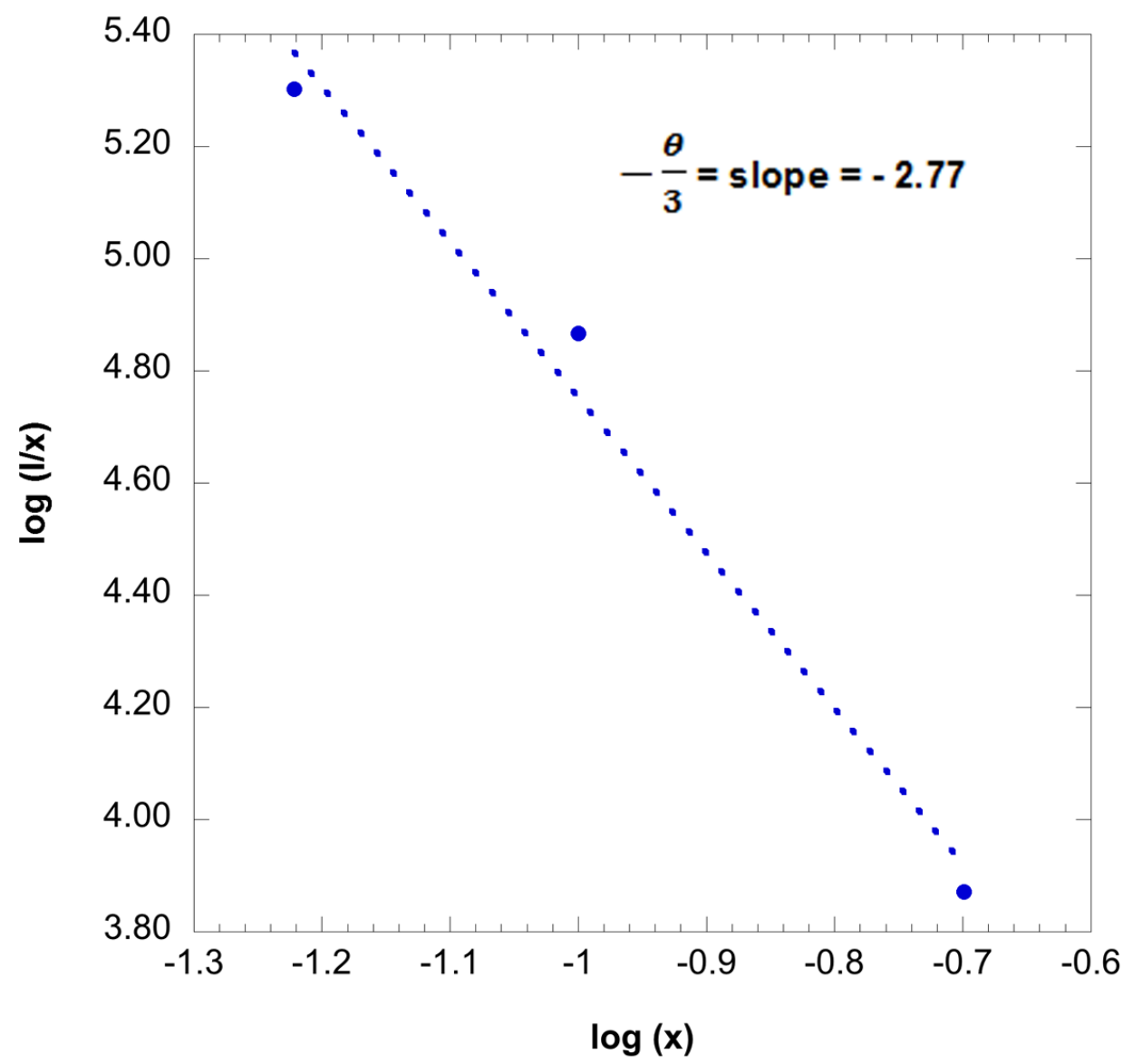

Figure 8. The relationship between the $\log (I / x)$ and $\log (x)$ of $\mathrm{Ca}_{1-\mathrm{x}} \mathrm{Eu}_{\mathrm{x}} \mathrm{MgSi}_{2} \mathrm{O}_{6} . I=$ emission intensity, and $x=$ concentration of $\mathrm{Eu}^{2+}(x=0.06,0.1$, and 0.2$)$. 


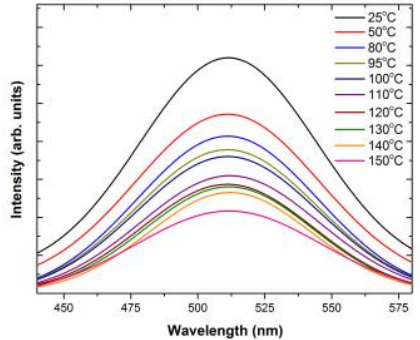

(a)

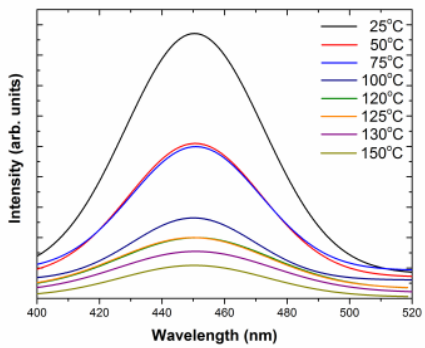

(b)

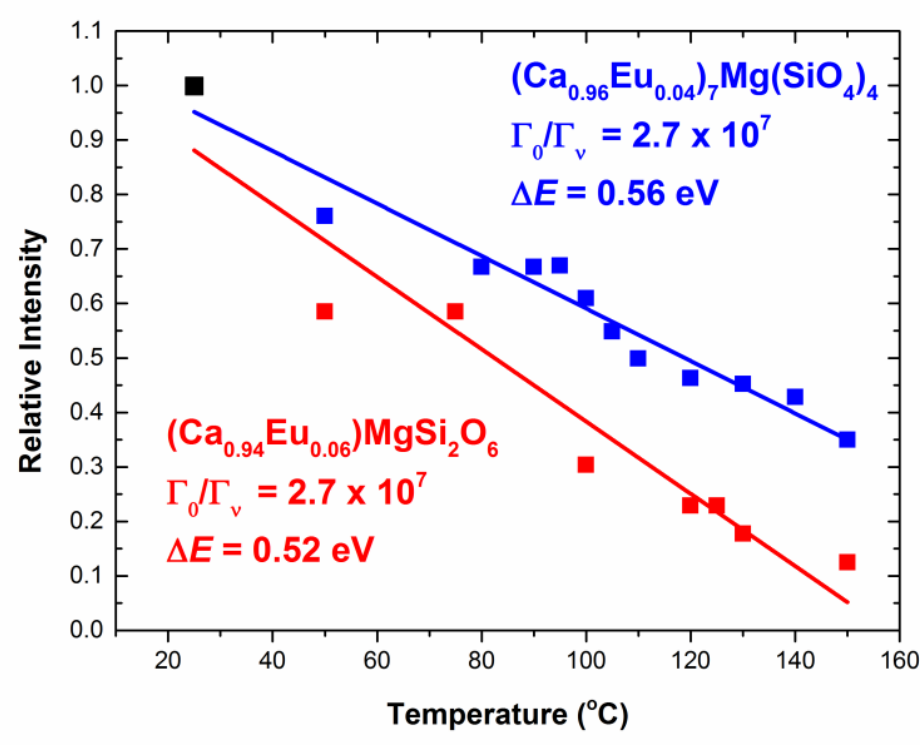

(c)

Figure 9. The emission intensity $(I)$ of the photoluminescence spectra as a function of temperature for (a) $\left(\mathrm{Ca}_{0.96} \mathrm{Eu}_{0.04}\right)_{7} \mathrm{Mg}\left(\mathrm{SiO}_{4}\right)_{4}$, (b) $\mathrm{Ca}_{0.94} \mathrm{Eu}_{0.06} \mathrm{Mg}\left(\mathrm{SiO}_{3}\right)_{2}$. (c) Plot of the relative intensity as a function of temperature from the data in (a) and (b). $\Delta E=$ activation energy and $\Gamma_{0}$ is the attempt rate for thermal quenching at $T=\infty$, and $\Gamma_{v}$ is the radiative decay rate of the $5 \mathrm{~d}$ state of $\mathrm{Eu}^{2+}$. 